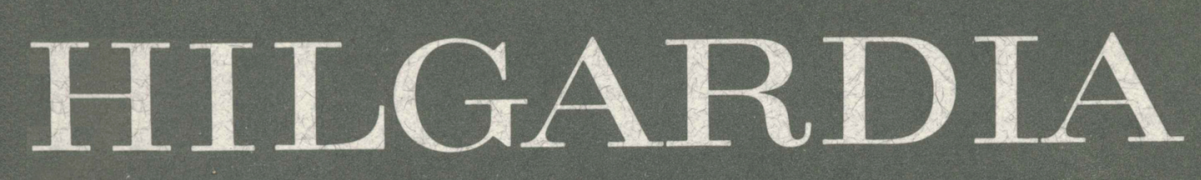

A JOURNAL OF AGRICULTURAL SCIENCE PUBLISHED BY THE CALIFORNIA AGRICULTURAL EXPERIMENTSTATION

Volume 41, Number $6 \cdot$ October, 1971

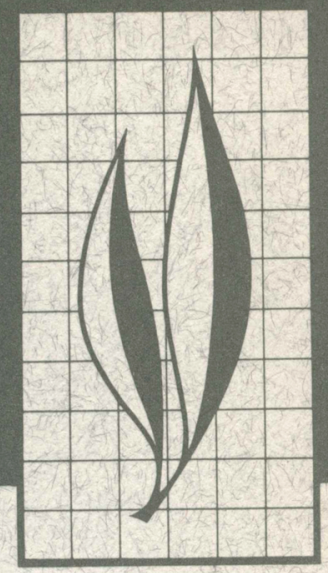

\title{
Influence of Processing Method on Energy Utilization of Feed Grains
}

\author{
W. N. Garrett, G. P. Lofgreen, J. L. Hull
}




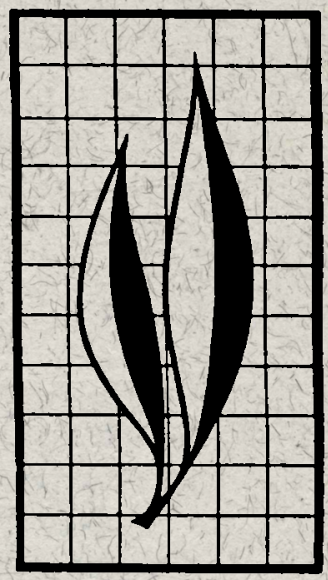

A comparative slaughter-feeding trial technique was used to determine the influence of various steam-processing treatments on the energy utilization and feeding value of wheat, corn, barley and milo for feedlot cattle. Processing of wheat, corn and barley by various steam-pressure-time combinations did not consistently improve their value compared to processing by a standard steamrolling procedure. Steam-pressure processing of milo resulted in a 10 per cent improvement in the net energy for gain value of high-grain rations. The optimum time-pressure steam treatment was approximately $1.5 \pm .5$ minutes at $3.5 \pm .5 \mathrm{~kg} / \mathrm{cm}^{2}$. The improvement in the feeding value of steam-pressure-processed milo seems to be due to small, but additive, beneficial effects associated with an improvement in energy digestibility, more rapid rumen fermentation, and decreased food intake.

\section{THE AUTHORS:}

W. N. Garrett is Professor of Animal Science and Nutritionist in the Experiment Station, University of California, Davis.

G. P. Lofgreen is Professor of Animal Science and Nutritionist in the Experiment Station, University of California, Imperial Valley Field Station, El Centro.

J. L. Hull is Specialist in Animal Science, University of California, Davis. 


\section{Influence of Processing Method on Energy Utilization of Feed Grains $^{1}$}

\section{INTRODUCTION}

Basic STUDies on PRoduction of volatile fatty acids, principally acetic, propionic and butyric, by microflora associated with the digestive tract of the ruminant indicated that heat-processed starch and grain could produce a greater proportion of propionic acid (Balch et al., 1955; Armstrong et al., 1957; Ensor et al., 1959; Shaw et al., 1959). Additional work by many investigators (see Blaxter, 1962, and Blaxter and Wainman, 1964) has indicated that there is a higher efficiency of utilization of food energy for growth and fattening from rations which give rise to greater amounts of propionic acid than of acetic acid. These findings led to the adaptation and development of continuous-flow, high-capacity steam-pressure processing equipment for feed grains.

The experiments conducted in this investigation were to determine if various methods of steam processing grain would improve the performance of fattening beef cattle or influence the efficiency of energy utilization of fattening rations.

\section{METHODS}

The results of eight separate feeding experiments are reported. (Three experiments were conducted under a contract with the U.S.D.A.) A short-term experiment with fistulated steers, and a slaughter trial with sheep designed to partition the amount of grain digested in the different segments of the gastrointestinal tract, is also reported.

The experiments had several factors in common. All utilized the comparative slaughter-feeding trial technique (Garrett et al., 1959; Lofgreen, 1965; Lofgreen and Garrett, 1968) in which carcass density was the key for resolving body composition. The relationships between carcass density and the various components of the animal body are given by Garrett and Hinman
(1968); this information on body composition was used to determine energy gain and net energy value of rations. The usual measures of feedlot performance and carcass value were also obtained in each experiment. Animal weights and weight gains are based on shrunk weights taken after 16 to 18 hours without feed or water, and on empty body weights calculated by a regression equation relating warm carcass weight to empty body weight (Garrett and Hinman, 1968). Energy gain and net energy data are based on empty body weights.

Net energy values $\left(\mathrm{NE}_{\mathrm{m}}\right.$ and $\mathrm{NE}_{\mathrm{g}}$ ) were determined from the parameters energy gain, metabolizable energy intake (ME), feed intake, and metaboliz-

\footnotetext{
${ }^{1}$ Submitted for publication December 11, 1970.
} 
able energy content of the ration. The average heat production of all steers at zero level of energy intake was assumed to be $77 \mathrm{~W}^{0} \mathbf{i k g}_{\mathbf{k g}} \mathrm{kcal}$ (Lofgreen and Garrett, 1968). Heat production is the difference between ME intake and energy balance (gain in this instance). The regression of the log of heat production per unit $\mathrm{W}_{\mathbf{k g}}^{0.75}$ against metabolizable energy per unit $\mathrm{W}_{\mathrm{kg}}^{0.75}$ when forced through the point of heat production at zero intake of $\mathrm{ME}\left(77 \mathrm{~W}_{\mathbf{k g}_{\mathbf{g}}}{ }^{75}\right)$, results in a plot from which the $\mathrm{ME}$ required for maintenance can be calculatedthat is, the point where HP = ME. (See figure 1 for an example plot.) Total feed intake can then be partitioned into the amount of feed required for maintenance and for production. $\mathrm{NE}_{\mathrm{m}}$ is then $77 \mathrm{~W}_{\mathbf{k g}}^{0.75}$ per $\mathrm{kg}$ of feed for maintenance, and $\mathrm{NE}_{\mathrm{g}}$ is energy gain per $\mathrm{kg}$ of feed left for production. All steers were implanted with diethylstilbestrol. Animals in most trials were individually fed, and had access to feed at all times. (There were exceptions to this, as noted in the more detailed explanation of the experimental design for each individual experiment.)

\section{Digestion trials}

Digestion trials were conducted on some of the rations used in these experiments. Total collection of feces for 7 days (trial 2) or 10 days (trials 3 and 5) were made by means of a harness and collection bags after the animals (previously adjusted to high-concentrate diets) were fed the same ration for at least 10 days in a preliminary period. All data for the digestion experiment associated with trial 1 had to be discarded when it was discovered that animals on these high-concentrate rations had been consuming feces in the exercise lot. A change in management practices prevented this from occurring in subsequent experiments.

Commercially available steam-pressure processing equipment was used to steam the grain under pressure. Grain was rolled after steam treatment by a $45.7 \times 45.7 \mathrm{~cm}$ Memco roller mill set with no tolerance between the rollers. If grain was to be ground, a hammermill with a $0.32 \mathrm{~cm}$ or $0.64 \mathrm{~cm}$ screen was used for milo and barley, respectively. Table 1 shows ingredient composition of the diets for all trials.

Trial 1. This experiment had a factorial design involving three kinds of grain (California barley, Texas Panhandle irrigated milo and No. 2 yellow corn) with each grain being fed at 40,60 and 80 per cent of the ration. Hereford yearling steers were divided according to weight into three replications and then randomly assigned to treatments. The grains were subjected to one of the following processes prior to mixing into the ration:

dry rolled with no steam treatment;

rolled after 8 minutes steaming at near atmospheric pressure;

rolled after 1.5 minutes steaming at $1.4 \mathrm{~kg} / \mathrm{cm}^{2}$;

rolled after 1.5 minutes steaming at $1.4 \mathrm{~kg} / \mathrm{cm}^{2}$;

The animals in the heavy replication were slaughtered after 84 days, with the final slaughter of the lighter replications after 112 and 140 days of feeding.

Trial 2. This study involved wheat, corn, barley and milo, all from California sources and each fed at two levels, 64 and 84 per cent. The grains were subjected to one of the following treatments prior to mixing in the complete ration:

rolled after 8 minutes steaming at near atmospheric pressure; rolled after 1.5 minutes steaming at

$1.4 \mathrm{~kg} / \mathrm{cm}^{2}$; rolled after 1.5 minutes steaming at $4.2 \mathrm{~kg} / \mathrm{cm}^{2}$; rolled after 20 minutes steaming at near atmospheric pressure.

Hereford steer calves were randomly assigned to the treatments. The experi- 


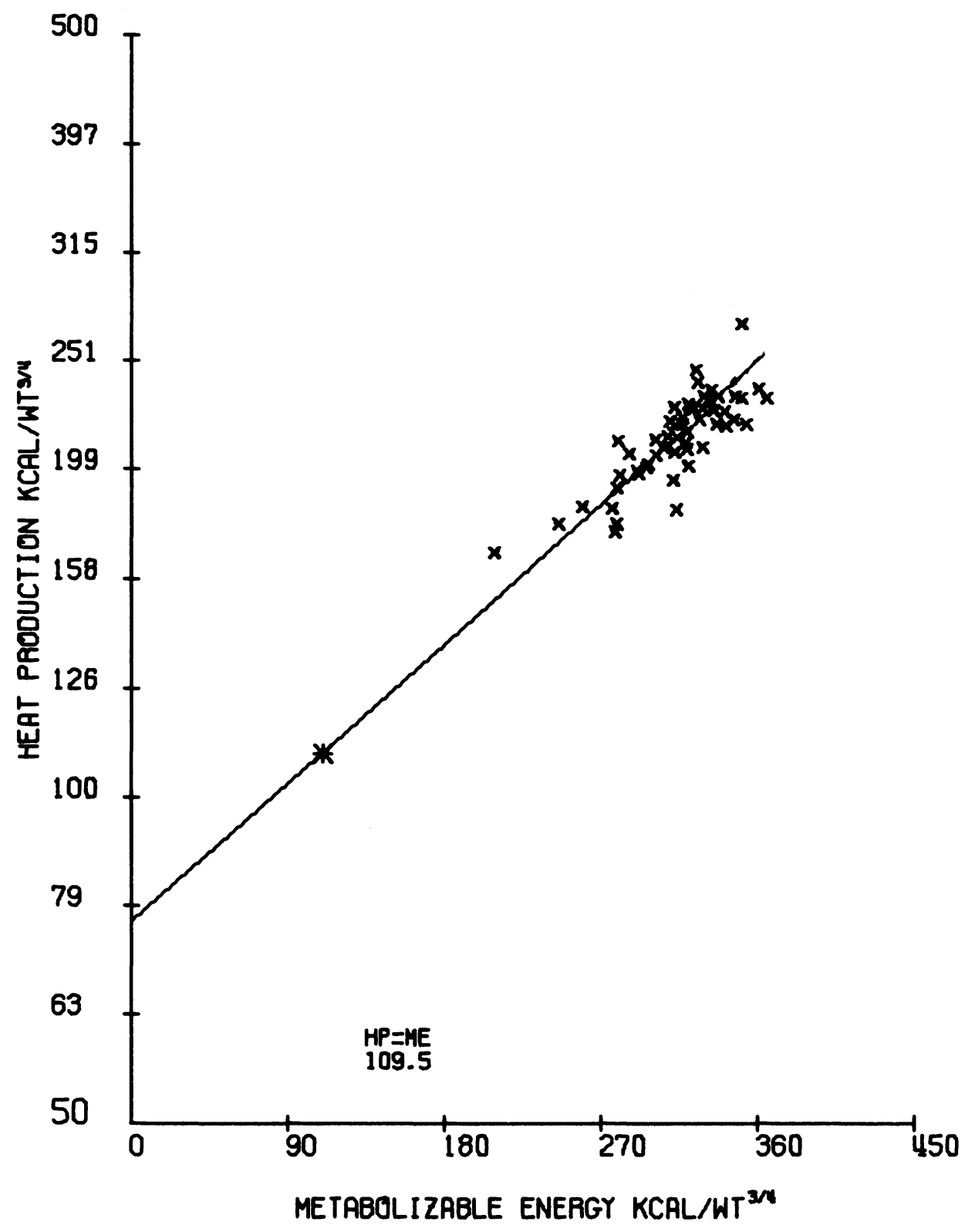

Fig. 1. Sample plot of data used to determine the metabolizable energy required for maintenance. This example is for all steers consuming milo rations in trial 3. 
TABLE 1

COMPOSITION OF DIETS, TRIALS 1-8*

\begin{tabular}{|c|c|c|c|c|c|c|c|c|}
\hline \multirow{3}{*}{$\begin{array}{l}\text { Ingredients other } \\
\text { than grain }\end{array}$} & \multicolumn{8}{|c|}{ Percentage of grain and other ingredients in diet $\uparrow$} \\
\hline & \multicolumn{3}{|c|}{ Trial 1} & \multicolumn{2}{|c|}{ Trial 2} & \multirow{2}{*}{$-\mid \begin{array}{c}\text { Trials } \\
3 \text { and } 6 \\
\begin{array}{c}\text { Grain as } \\
72 \text { per cent } \\
\text { of diet }\end{array}\end{array}$} & \multirow{2}{*}{$\frac{\text { Trial 4 }}{\begin{array}{c}\text { Grain as } \\
70 \text { per cent } \\
\text { of diet }\end{array}}$} & \multirow{2}{*}{$\frac{\begin{array}{c}\text { Trials } \\
5,7,8 \ddagger\end{array}}{\begin{array}{c}\text { Grain as } \\
71 \text { per cent } \\
\text { of diet }\end{array}}$} \\
\hline & $\begin{array}{c}\text { Grain as } \\
40 \text { per cent } \\
\text { of diet }\end{array}$ & $\begin{array}{c}\text { Grain as } \\
60 \text { per cent } \\
\text { of diet }\end{array}$ & $\begin{array}{l}\text { Grain as } \\
80 \text { per cent } \\
\text { of diet }\end{array}$ & $\begin{array}{c}\text { Grain as } \\
64 \text { per cent } \\
\text { of diet }\end{array}$ & $\begin{array}{c}\text { Grain as } \\
84 \text { per cent } \\
\text { of diet }\end{array}$ & & & \\
\hline Alfalfa hay.......... & 23.5 & 12.9 & 2.3 & 10.0 & 2.3 & 8.0 & 10.0 & 11.0 \\
\hline Oat hay $\ldots \ldots \ldots \ldots \ldots$ & $\ldots$ & $\ldots$ & $\ldots$ & 10.0 & 2.3 & $\ldots$ & 5.0 & $\ldots$ \\
\hline Sudan hay . . . . . . . . & 9.4 & 5.2 & 0.9 & $\ldots$ & $\ldots$ & 4.0 & $\ldots$ & 4.0 \\
\hline Beet pulp ........ & 8.9 & 4.9 & .9 & 6.0 & 1.4 & 4.0 & 5.0 & $\ldots$ \\
\hline Cottonseed meal. & 4.7 & 2.6 & .5 & $\ldots$ & $\ldots$ & 3.0 & $\ldots$ & 5.0 \\
\hline Molasses......... & 10.0 & 10.0 & 10.0 & 5.0 & 5.0 & 5.0 & 5.0 & 5.0 \\
\hline Fat.......... & 2.0 & 2.0 & 2.0 & 2.0 & 2.0 & 2.0 & 2.0 & 2.0 \\
\hline Urea................. & $\ldots$ & 0.6 & 1.2 & 1.0 & 1.0 & 1.0 & 1.0 & 0.7 \\
\hline Trace mineral salt....... & 1.0 & 1.0 & 1.0 & 1.0 & 1.0 & 0.4 & 1.0 & .5 \\
\hline Dicalcium phosphate.... & 0.5 & 0.4 & 0.4 & 0.6 & 0.6 & .3 & 0.6 & .2 \\
\hline Oystershell flour........ & $\cdots$ & .4 & .8 & .4 & .4 & .3 & .4 & $\ldots$ \\
\hline Calcium chloride.. & $\ldots$ & $\ldots$ & $\ldots$ & $\ldots$ & $\ldots$ & $\ldots$ & $\ldots$ & .6 \\
\hline
\end{tabular}

* Diets were formulated to contain 12 to 13 per cent crude protein, at least 0.4 per cent calcium and 0.3 per cent phosphorus. Vitamin A was added to supply at least $2200 \mathrm{IU}$ per $\mathrm{kg}$ of mixed feed.

† Grains were: Trial 1-corn, barley and milo; Trial 2-wheat, corn, barley and milo; Trial 3-barley and milo; Trial 4milo; Trial 5-wheat, milo; Trials 6, 7 and 8 - milo.

$\ddagger$ Trial 8. Urea 0.5 and calcium chloride 1.0; dicalcium phosphate deleted.

mental design was a $4 \times 4 \times 2 \times 3$ factorial, with days on feed as the final factor. The cattle were slaughtered in three groups starting at 168 days of feeding with the final group being fed for 210 days.

Trial 3. California barley and milo were processed by six different methods and fed to randomly assigned short-yearling steers. The six procedures used to process each grain were as follows:

rolled after 8 minutes steaming at

near atmospheric pressure;

rolled after 1 minute steaming at

$1.8 \mathrm{~kg} / \mathrm{cm}^{2}$;

rolled after 1 minute steaming at

$3.5 \mathrm{~kg} / \mathrm{cm}^{2}$;

rolled after 1 minute steaming at

$5.3 \mathrm{~kg} / \mathrm{cm}^{2}$;

rolled after 20 minutes steaming at

near atmospheric pressure;

ground by hammermill without steaming.

The cattle were slaughtered in three groups 1 week apart starting after 140 days of feeding.

Trial 4. Milo was fed as ground or rolled grain after steam processing for 8 minutes at atmospheric pressure or for 1.5 minutes at $1.4,2.8$ and 5.6 $\mathrm{kg} / \mathrm{cm} .{ }^{2}$ The cattle were short-yearling steers; slaughter took place in four groups with an average feeding period of 121 days. Four fistulated steers were used in a Latin-square-designed experiment to determine volatile fatty acid levels in the rumen fluid. These animals were fed the rolled grain rations ad libitum, with collections made at 8:00 and 9:00 A.M. and 12:00 noon and 5:00 P.M. Rumen samples were handled by the method of Erwin (1961). Analysis was in an Aerograph $600 \mathrm{D}$ gas chromatograph at $155^{\circ} \mathrm{C}$. with a $0.3 \times 12.7 \mathrm{~cm}$ column packed with 15 per cent FAAP (Aerograph) and chromsorb W (acid washed, diethyldichlorosilane treated, 80/100 mesh).

Trial 5. Milo and wheat were fed after processing by three steaming procedures and a dry heat expansion method developed by the U.S.D.A. at Albany, California. These processing procedures were: 
steamed for 8 minutes at atmospheric pressure then rolled;

steamed for 1.5 minutes at 3.5 $\mathrm{kg} / \mathrm{cm}^{2}$ then rolled;

steamed for 1.5 minutes at 5.6

$\mathrm{kg} / \mathrm{cm}^{2}$ then rolled;

dry heat expansion by the U.S.D.A. method then rolled.

There were twelve animals in each treatment group; all animals were individually fed for 163 days. A digestion trial was conducted on the milo ration fed in this experiment, and samples taken from the rumen of these steers were analyzed for the volatile fatty acids as described for trial 4 .

Trials 6 and 7. Milo grain fed in these experiments was processed by steaming at atmospheric pressure for 8 minutes before rolling, or by steaming at a pressure of $3.5 \mathrm{~kg} / \mathrm{cm}^{2}$ for 1.5 minutes and then rolling. In previous trials a depressed intake was noted for the rations containing the steam-pressure-processed milo. To eliminate some of the variation in animals' response due to feed intake, some steers in each trial were pair-fed. That is, the steers were paired on the basis of size and fed the same amount of their assigned diets with the animal consuming the least feed regulating the intake of his pairmate. In trial 6 the ad libitum-fed animals were in groups of 18 steers. One group received the steam-pressureprocessed milo ration prepared fresh each working day. This group was included to determine if our standard procedure of processing feed at 10 - to 14-day intervals was resulting in a response that might be different if fresh feed was prepared daily. All animals in trial 7 were individually fed.

Trial 8. In previous experiments it was necessary to assume a level of fasting heat production in order to calculate net energy values for the ration. This was a reasonable assumption, since in each trial the animals originated in one herd and had been treated in an iden- tical manner before random assignment to experimental treatments. Nevertheless, it was still possible that treatments imposed were influencing the feed required for maintenance and, consequently, the net energy value for maintenance and gain. This experiment was designed to determine the energy utilization for gain of two rations without the need for assumptions regarding fasting heat production. A secondary purpose of the experiment was to determine if the difference in water content of the rations (caused by more moisture being added to the grain by steam-pressure processing) effected feed consumption and animal response. The ration contained milo processed by steaming at atmospheric pressure for 8 minutes before rolling, and by processing under steam pressure of $3.5 \mathrm{~kg} / \mathrm{cm}^{2}$ for 1.5 minutes before rolling.

All animals were individually fed for an average of 114 days. Each ration was fed at a level estimated to be near the maintenance requirement and ad libitum. The ration containing the added water with the steam rolled grain (8 minutes at atmospheric pressure) was fed only at the ad libitum level.

\section{Digestion study using fistulated steers and intact wethers}

These experiments were conducted on rations containing 80 per cent milo processed by rolling after steaming at atmospheric pressure for 8 minutes, or by rolling after exposure to a steampressure of $3.5 \mathrm{~kg} / \mathrm{cm}^{2}$ for 1.5 minutes. The steers had rumen and abomasal fistulas with digestibility in the various compartments being estimated by the lignin-ratio technique. Eight 15-monthold crossbred wethers weighing $65 \mathrm{~kg}$ were fed the same diets on an ad libitum basis. Fresh food was added daily at 8:00 A.M. and 4:00 P.M. The sheep were slaughtered after 5 weeks of feed- 
128

ing. Two animals from each diet were killed at 10:00 A.M. and 12 noon to allow collection of samples at a time of high fermentative activity in the rumen. Samples were obtained from the rumen and the abomasum so that estimates of digestibility could be ob-
Garrett et al.: Influence of Processing Method

tained for those areas of the digestive tract anterior and posterior to the abomasum. The lignin ratio technique was used for this purpose. Fermentation rates of rumen contents were measured using in vitro gas production as an index of fermentation.

\section{RESULTS}

Tables 2 and 3 show the chemical composition of rations and the individual grains. Table 4 gives the dry matter content of grain at time of mixing into the rations.

Milo and corn take up more moisture than barley during the various steamprocessing treatments, and more mois- ture is added to the grain at higher steam pressures and with longer exposure to the steam. Since ingredients for all rations were weighed into the mixture on an "as supplied" basis, these differences mean that the actual amount of grain dry matter was not exactly the same in all comparable rations. In most

TABLE 2

PROXIMATE ANALYSIS AND GROSS ENERGY CONTENT OF THE DIETS*

\begin{tabular}{|c|c|c|c|c|c|c|c|}
\hline \multirow[b]{2}{*}{ Trial } & \multirow{2}{*}{ Grain } & \multirow{2}{*}{$\begin{array}{l}\text { Per cent } \\
\text { of grain } \\
\text { in the diet }\end{array}$} & \multicolumn{5}{|c|}{ Proximate constituents } \\
\hline & & & $\begin{array}{l}\text { Crude } \\
\text { protein }\end{array}$ & $\begin{array}{l}\text { Crude } \\
\text { fiber }\end{array}$ & $\begin{array}{l}\text { Ether } \\
\text { extract }\end{array}$ & Ash & $\begin{array}{c}\text { Gross } \\
\text { energy }\end{array}$ \\
\hline \multirow{10}{*}{1} & & & & \multicolumn{2}{|c|}{ per cent } & & $\mathrm{kcal} / \mathrm{g}$ \\
\hline & & 40 & 14.4 & 13.2 & 4.0 & 8.2 & 4.31 \\
\hline & Barley & 60 & 13.4 & 9.1 & 3.9 & 7.1 & 4.31 \\
\hline & & 80 & 13.6 & 5.2 & 3.5 & 5.9 & 4.28 \\
\hline & & 40 & 14.5 & 12.3 & 4.4 & 8.3 & 4.33 \\
\hline & Corn & 60 & 13.9 & 7.7 & 4.7 & 7.2 & 4.35 \\
\hline & & 80 & 13.6 & 2.8 & 5.0 & 5.5 & 4.35 \\
\hline & & 40 & 14.4 & 11.6 & 4.0 & 8.0 & 4.33 \\
\hline & Milo & 60 & 13.7 & 7.3 & 5.0 & 7.0 & 4.35 \\
\hline & & 80 & 14.0 & 2.7 & 4.4 & 5.6 & 4.31 \\
\hline \multirow{8}{*}{2} & \multirow{2}{*}{ Wheat } & 64 & 14.8 & 8.8 & 3.0 & 5.8 & 4.38 \\
\hline & & 84 & 13.8 & 3.8 & 3.2 & 4.0 & 4.41 \\
\hline & \multirow{2}{*}{ Corn } & 64 & 13.2 & 9.2 & 4.8 & 5.9 & 4.48 \\
\hline & & 84 & 11.0 & 3.8 & 4.9 & 3.4 & 4.50 \\
\hline & \multirow{2}{*}{ Barley } & 64 & 13.0 & 11.0 & 2.8 & 5.8 & 4.43 \\
\hline & & 84 & 12.5 & 6.3 & 3.2 & 4.6 & 4.42 \\
\hline & & 64 & 14.2 & 8.9 & 3.3 & 5.4 & 4.44 \\
\hline & & 84 & 12.5 & 3.9 & 3.7 & 4.2 & 4.46 \\
\hline \multirow{2}{*}{3} & Barley & 72 & 17.2 & 10.0 & 2.8 & 4.9 & 4.44 \\
\hline & Milo & 72 & 15.3 & 6.8 & 3.7 & 4.5 & 4.47 \\
\hline 4 & Milo & 70 & 14.1 & 6.9 & 6.8 & 4.1 & 4.38 \\
\hline \multirow{2}{*}{5} & Milo & 71 & 15.9 & 6.9 & 4.0 & 4.9 & 4.50 \\
\hline & Wheat & 71 & 15.2 & 7.1 & 3.3 & 4.8 & 4.46 \\
\hline 6 & Milo & 72 & 14.7 & 6.4 & 3.7 & 4.5 & 4.46 \\
\hline 7 & Milo & 71 & 15.4 & 7.5 & 4.0 & 4.8 & $\ldots$ \\
\hline 8 & Milo & 71 & 14.4 & 7.5 & 3.5 & 4.5 & $\ldots$ \\
\hline
\end{tabular}

* Dry basis. 
TABLE 3

PROXIMATE ANALYSIS AND WEIGHT PER VOLUME OF GRAINS*

\begin{tabular}{|c|c|c|c|c|c|c|}
\hline Trial & Grain & Weight & $\begin{array}{c}\text { Crude } \\
\text { protein }\end{array}$ & $\begin{array}{l}\text { Crude } \\
\text { fiber }\end{array}$ & $\begin{array}{c}\text { Ether } \\
\text { extract }\end{array}$ & Ash \\
\hline \multirow{6}{*}{1} & & $\mathrm{~kg} /$ liter & \multicolumn{4}{|c|}{ per cent } \\
\hline & Barley & 0.62 & 9.6 & 4.6 & 1.8 & 2.1 \\
\hline & Corn & .75 & 10.5 & 1.9 & 3.0 & 1.4 \\
\hline & Milo & .77 & 11.0 & 1.6 & 2.5 & 1.5 \\
\hline & Wheat & .77 & 12.6 & 2.0 & 1.5 & 1.9 \\
\hline & Corn & .71 & 10.0 & 1.8 & 2.0 & 1.3 \\
\hline 2 & Barley & .62 & 10.6 & 4.9 & 1.3 & 2.5 \\
\hline & Milo & .72 & 10.8 & 2.0 & 2.2 & 1.8 \\
\hline 3 & Barley & .61 & 15.1 & 5.9 & 1.2 & 2.8 \\
\hline 0 & Milo & .77 & 11.5 & 1.8 & 2.4 & 1.9 \\
\hline 5 & Milo & .77 & 11.9 & 2.2 & 2.1 & 2.0 \\
\hline 0 & Wheat & .77 & 11.8 & 2.2 & 1.6 & 1.9 \\
\hline 6 & Milo & & 11.5 & 2.4 & 2.9 & 2.1 \\
\hline 7 & Milo & & 11.7 & 2.2 & 2.2 & 2.0 \\
\hline 8 & Milo & & 10.8 & 2.1 & 2.0 & 1.7 \\
\hline
\end{tabular}

* Dry basis.

TABLE 4

PER CENT DRY MATTER OF GRAIN AT TIME OF MIXING INTO RATIONS

\begin{tabular}{|c|c|c|c|c|c|c|}
\hline \multirow{2}{*}{$\begin{array}{l}\text { Trial } \\
\text { number }\end{array}$} & \multicolumn{2}{|c|}{$\begin{array}{l}\text { Procedure used } \\
\text { to process the grain }\end{array}$} & \multicolumn{4}{|c|}{$\begin{array}{l}\text { Per cent dry matter in the various grains } \\
\text { at time of mixing the rations }\end{array}$} \\
\hline & $\begin{array}{l}\text { Steaming time } \\
\text { in minutes }\end{array}$ & $\begin{array}{l}\text { Steam } \\
\text { pressure }\end{array}$ & Milo & Corn & Barley & Wheat \\
\hline 1 & $\begin{array}{l}0^{*} \\
8 \\
1.5 \\
1.5\end{array}$ & $\begin{array}{l}0^{*} \\
\text { Atmospheric } \\
1.4 \mathrm{~kg} / \mathrm{cm}^{2} \\
4.2 \mathrm{~kg} / \mathrm{cm}^{2}\end{array}$ & $\begin{array}{l}87.5 \\
83.9 \\
81.0 \\
81.3\end{array}$ & $\begin{array}{l}87.6 \\
83.2 \\
83.9 \\
82.7\end{array}$ & $\begin{array}{l}91.9 \\
87.4 \\
86.3 \\
83.5\end{array}$ & \\
\hline 2 & $\begin{array}{l}8 \\
1.5 \\
1.5 \\
20\end{array}$ & $\begin{array}{l}\text { Atmospheric } \\
1.4 \mathrm{~kg} / \mathrm{cm}^{2} \\
4.2 \mathrm{~kg} / \mathrm{cm}^{2} \\
\text { Atmospheric }\end{array}$ & $\begin{array}{l}82.1 \\
82.0 \\
80.8 \\
81.2\end{array}$ & $\begin{array}{l}82.2 \\
81.0 \\
81.2 \\
81.0\end{array}$ & $\begin{array}{l}86.2 \\
86.2 \\
82.7 \\
84.4\end{array}$ & $\begin{array}{l}84.0 \\
83.6 \\
82.4 \\
83.1\end{array}$ \\
\hline 3 & $\begin{array}{l}0 \dagger \\
8 \\
1 \\
1 \\
1 \\
20\end{array}$ & $\begin{array}{l}\quad 0 \dagger \\
\text { Atmospheric } \\
1.8 \mathrm{~kg} / \mathrm{cm}^{2} \\
3.5 \mathrm{~kg} / \mathrm{cm}^{2} \\
5.3 \mathrm{~kg} / \mathrm{cm}^{2} \\
\text { Atmospheric }\end{array}$ & $\begin{array}{l}89.0 \\
86.2 \\
84.4 \\
82.4 \\
82.0 \\
84.1\end{array}$ & & $\begin{array}{l}90.9 \\
89.8 \\
86.2 \\
84.6 \\
84.6 \\
86.2\end{array}$ & \\
\hline 5 & $\begin{array}{l}8 \\
1.5 \\
1.5 \\
0 \ddagger\end{array}$ & $\begin{array}{c}\text { Atmospheric } \\
3.5 \mathrm{~kg} / \mathrm{cm}^{2} \\
5.6 \mathrm{~kg} / \mathrm{cm}^{2} \\
\text { of }\end{array}$ & $\begin{array}{l}85.3 \\
81.4 \\
81.3 \\
94.5\end{array}$ & & & $\begin{array}{l}88.8 \\
84.8 \\
84.4 \\
94.6\end{array}$ \\
\hline 6 & $\begin{array}{l}8 \\
1.5\end{array}$ & $\begin{array}{l}\text { Atmospheric } \\
3.5 \mathrm{~kg} / \mathrm{cm}^{2}\end{array}$ & $\begin{array}{l}87.8 \\
84.5\end{array}$ & & & \\
\hline 7 & $\begin{array}{l}8 \\
1.5\end{array}$ & $\begin{array}{l}\text { Atmospheric } \\
3.5 \mathrm{~kg} / \mathrm{cm}^{2}\end{array}$ & $\begin{array}{l}85.3 \\
82.3\end{array}$ & & & \\
\hline 8 & $\begin{array}{l}8 \\
1.5\end{array}$ & $\begin{array}{l}\text { Atmospheric } \\
3.5 \mathrm{~kg} / \mathrm{cm}^{2}\end{array}$ & $\begin{array}{l}86.5 \\
82.6\end{array}$ & & & \\
\hline
\end{tabular}

* No steam treatment, the grains were dry rolled.

$\dagger$ No steam treatment, the grains were ground by hammermill.

$\ddagger$ No steam treatment, the grains were rolled after being expanded by a dry heat treatment. 
comparisons these differences amount to 1 or 2 per cent, but for experiments which included grain not exposed to steam the differences are greater. The direction of the error involved would be toward a slightly more conservative estimate of the effect of steam processing.

\section{Results of trials 1 and 2}

The first two experiments were factorial arrangements in which more than one grain was fed. Each grain was fed at more than one level after being subjected to various steam treatments. These designs would provide adequate numbers of cattle if comparisons could be made across grains and levels. In spite of few significant grain $\times$ processing method interactions, it became apparent that feeding value of all grains was not being influenced in an identical manner by the same processing treatment. Therefore, the results are summarized by grain and processing treatment rather than by processing treatment across grains. Tables 5, 6 , and 7 summarize results of trial 1 for corn, barley and milo, respectively. The first column of table 19 indicates the approximate differences required for statistical significance in the response criteria. None of the differences in feedlot response or carcass characteristics attributable to the method of processing barley or corn is statistically significant. However, there appears to be a slight improvement in the feed/ gain ratio and $\mathrm{NE}_{\mathrm{g}}$ value of rations containing steam-pressure-processed corn.

Feedlot response of cattle fed milo processed by the different methods was not all the same. In general, cattle receiving rations containing milo processed for 1.5 minutes at $1.4 \mathrm{~kg} / \mathrm{cm}^{2}$ gained faster with the least amount of feed per unit of grain. Less feed was consumed by animals receiving the milo subjected to the most severe steam treatment $\left(1.5\right.$ minutes at $\left.4.2 \mathrm{~kg} / \mathrm{cm}^{2}\right)$.
Carcass characteristics were not influenced by the grain-processing procedures. Net energy for gain values were higher for milo rations containing steam-pressure-treated grain.

Significant $(\mathrm{P}<.05)$ grain $\times$ level interactions were present for final weight, feed intake, shrunk weight gain, and energy gain. Over-all appraisal indicates that cattle receiving the corn performed almost equally well at all levels. Performance of barley-fed cattle improved as the level of barley increased, and milo-fed cattle responded best to the 60 per cent level of grain. There were no significant differences due to kind of grain.

The results of trial 2 (tables $8,9,10$ and 11) are difficult to interpret, as it now appears that the critical conclusions should probably be drawn from the processing method within grain comparisons rather than comparisons across all grains-as was the original intention when the experiment was designed. However, the general picture is not greatly different from that of trial 1 ; that is, the feedlot response of cattle receiving milo processed by the various steam treatments is somewhat different from the response of steers receiving the other grains. A marked depression in feed intake of the ration containing milo processed for 1.5 minutes at 4.2 $\mathrm{kg} / \mathrm{cm}^{2}$ is apparent. This reduced food intake resulted in lower weight and energy gains of cattle receiving the treatment. Most measures of carcass merit were also significantly reduced $(\mathrm{P}<$ $.05)$. The $\mathrm{NE}_{\mathrm{g}}$ value for the ration containing milo processed at the higher steam pressure $\left(4.2 \mathrm{~kg} / \mathrm{cm}^{2}\right)$ was as high as any determined in trial 2 . This indicates good utilization of the energy consumed.

Cattle receiving milo processed at the lower steam pressure $\left(1.4 \mathrm{~kg} / \mathrm{cm}^{2}\right)$ gained faster and more efficiently than did cattle receiving milo processed by the other procedures. This trend is similar to findings in trial 1 , but differences 


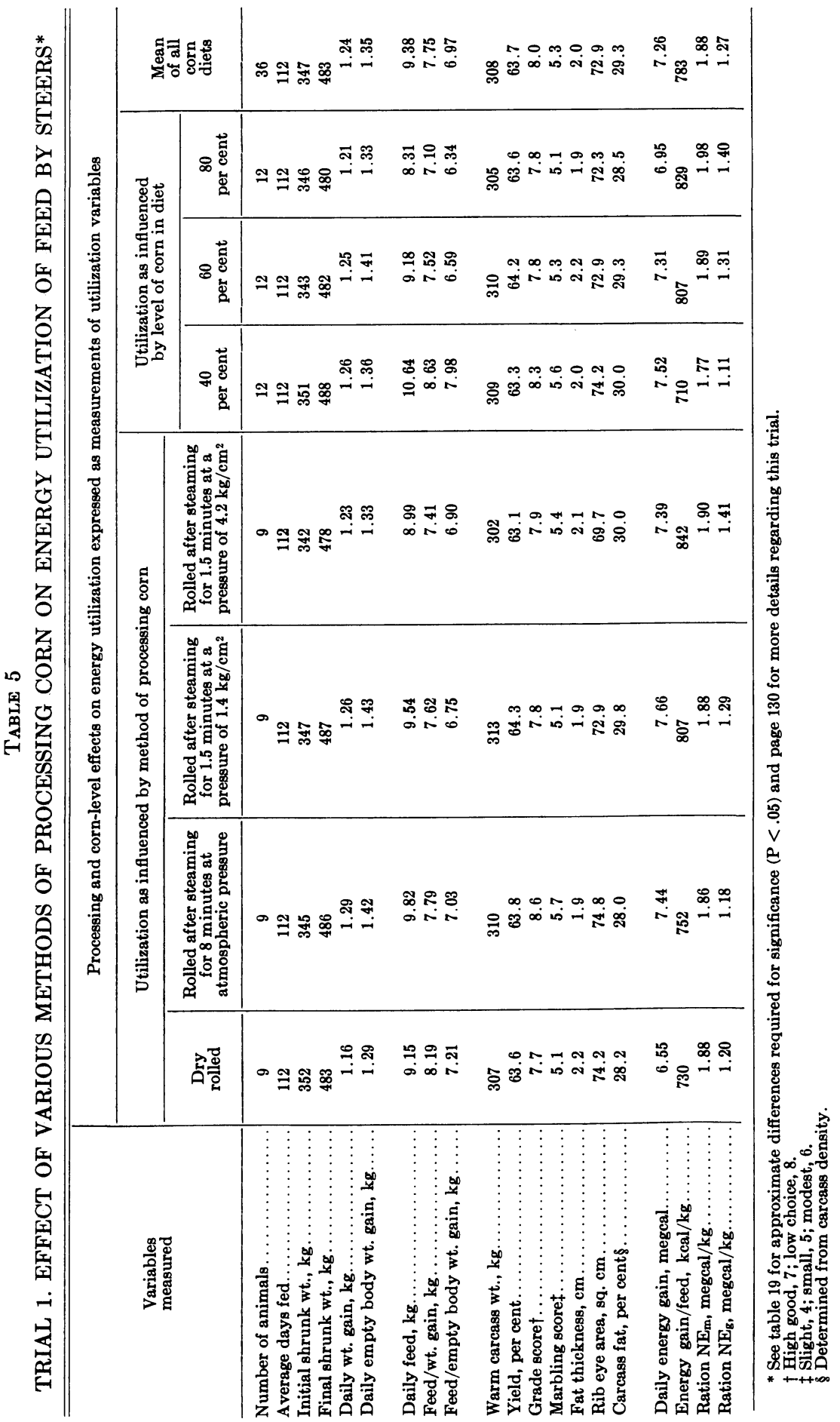




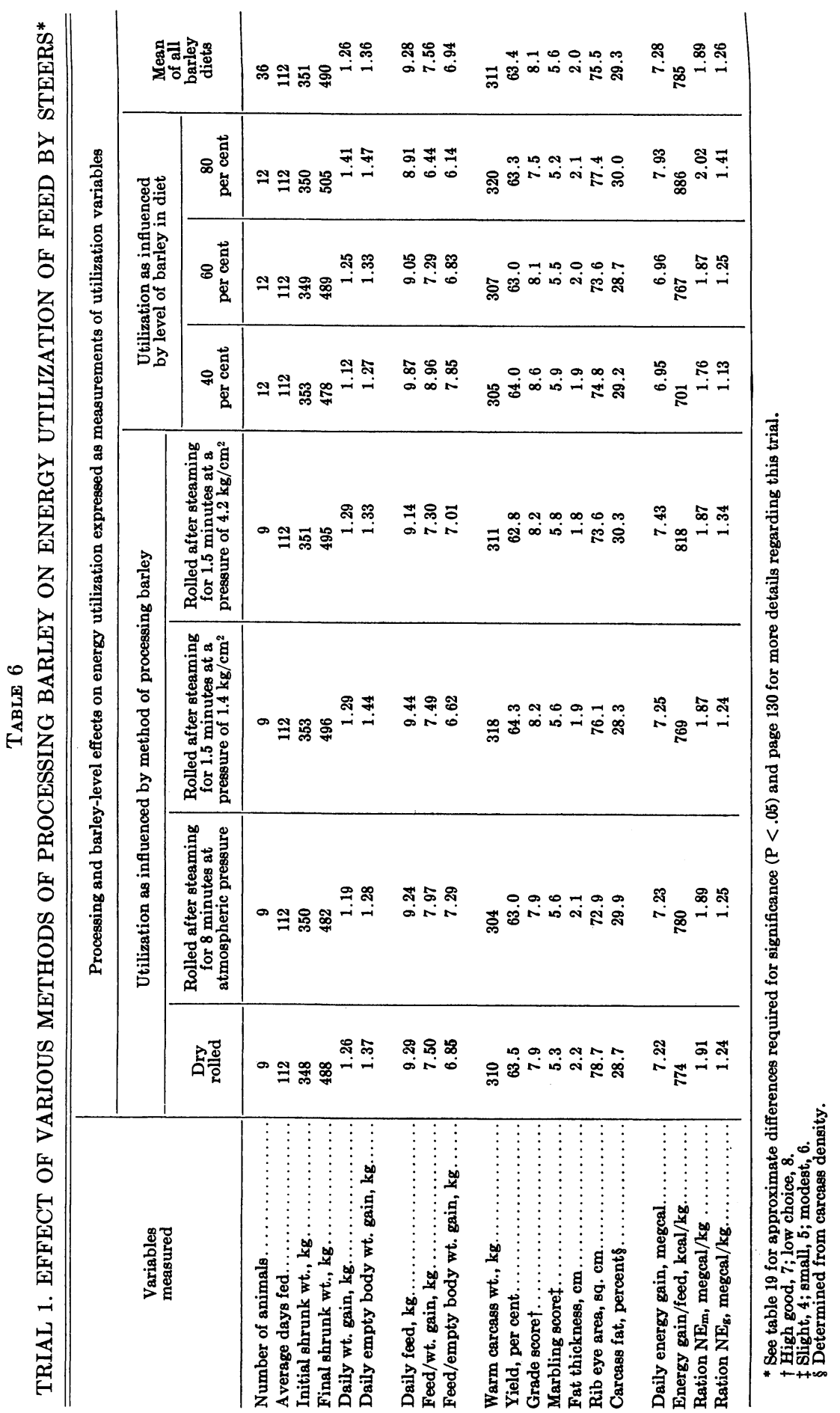




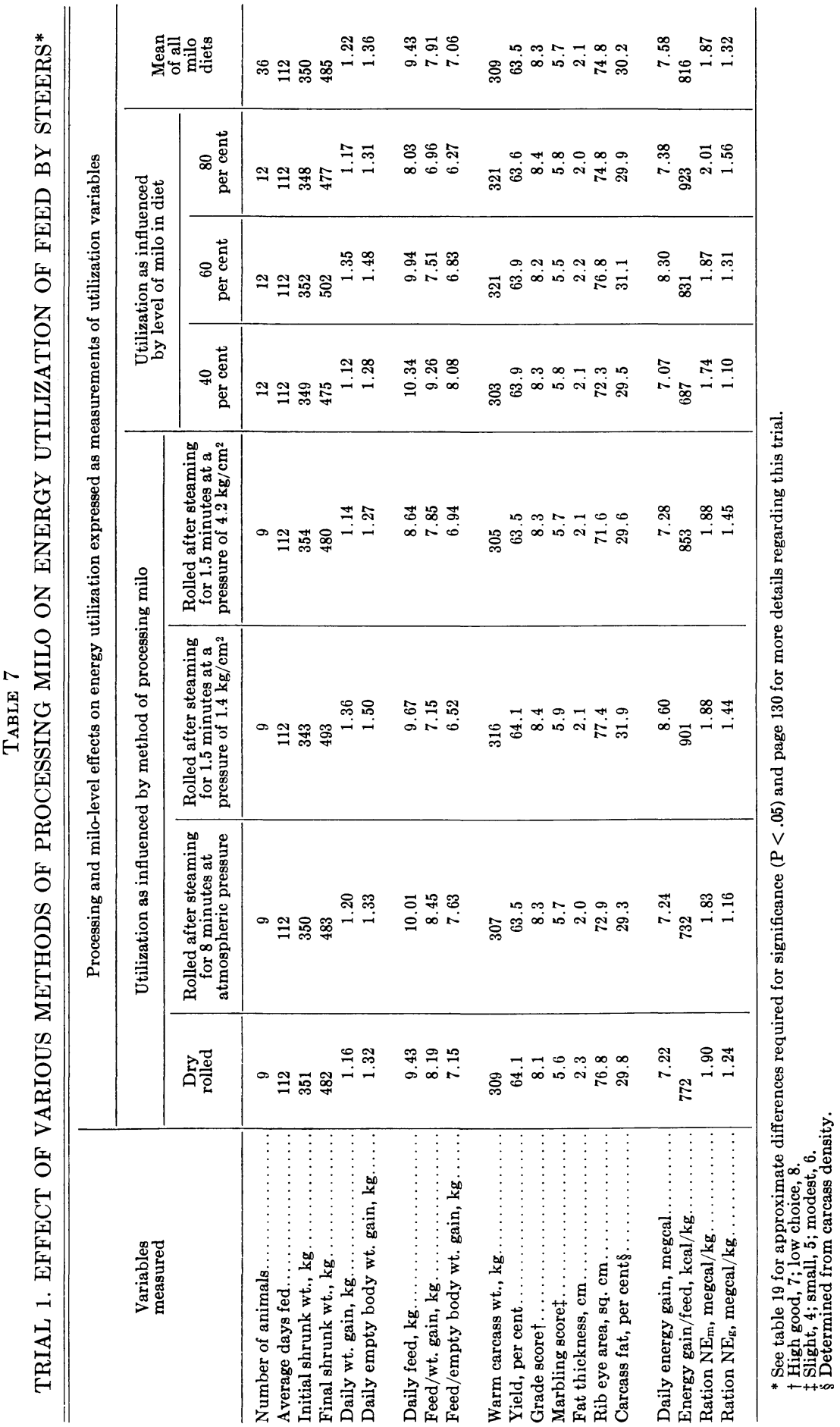


did not reach statistically significant levels.

There was no difference in feedlot response of steers receiving 64 or 84 per cent grain diets beyond the expected decrease in food intake, and an increased apparent feed efficiency for those receiving the 84 per cent grain rations. Carcass yields and rib-eye areas were significantly higher for animals receiving the 64 per cent grain ration, but adjusting rib-eye area by co-variance to equal carcass weights eliminated this difference. Differences in carcass yields might be similarly explained. Judging by feed efficiency and $\mathrm{NE}_{\mathrm{g}}$ figures, grains rank as follows in the order of decreasing value: corn, wheat, milo, barley. However, except for the corn-barley comparisons most differences between grains were not statistically significant.

\section{Results of trials 3, 4, and 5}

In trial 3 (tables 12 and 13) there are no important significant $(\mathrm{P}<.05)$ differences in feedlot response of cattle receiving the barley rations that can be attributed to the processing method. There is a trend to poorer utilization of the ground grain as compared to steamtreated grain; this is particularly evident in the $\mathrm{NE}_{\mathrm{g}}$ figures and, to some extent, in the empty-body feed efficiency data. Results with milo in trial 3 show a definite advantage in the feed/ gain ratio for milo processed by exposure to a steam pressure of $3.5 \mathrm{~kg} / \mathrm{cm}^{2}$ for 1 minute over most other methods of preparing the grain. Ground milo and milo processed by steaming for 20 minutes at atmospheric pressure was less well utilized $\left(\mathrm{NE}_{\mathrm{g}}\right.$ and feed efficiency figures) than milo processed by the other procedures. In this trial, processing milo by the most severe steam treatment ( 1 minute at 5.3 $\mathrm{kg} / \mathrm{cm}^{2}$ ) did not result in the marked depression in feed intake or daily gain seen in trial 2 , but some decrease was apparent in these parameters. As in previous experiments, measures of carcass value were relatively insensitive to the method of processing the grain.

In trial 4 (table 14) milo alone was fed to determine if rolling it after steam treatment was essential to the improved utilization shown in the previous trials. In this experiment, the method of steam-pressure-processing the milo did not significantly influence daily gain or the various measures of carcass value when compared to the regular steam-rolled grain. Feed efficiency was apparently improved by all steam-pressure treatments, but the animals were group-fed and the statistical significance of this apparent improvement cannot be tested. The $\mathrm{NE}_{\mathrm{g}}$ figures support the observation that efficiency of energy utilization of milo can be favorably influenced by certain steampressure treatments.

The differences in animal response due to rolling or grinding grain after steam treatments are not consistent for all parameters. Over-all differences are not statistically significant - the important finding is that an improved utilization of steam-pressure-processed milo was apparent whether processed grain was ground or rolled.

Table 15 summarizes information concerning response of steers fed the processed wheat in trial 5 . Less feed was consumed $(\mathrm{P}<.05)$ when cattle were fed the ration containing wheat processed either for 1.5 minutes at 3.5 $\mathrm{kg} / \mathrm{cm}^{2}$ or for the same time at 5.6 $\mathrm{kg} / \mathrm{cm}^{2}$ of steam-pressure. Gains were lower on these treatments (approached significance $(\mathrm{P}<.05)$ but feed efficiency was not influenced. Cattle fed the rolled dry-heat-treated wheat consumed an amount intermediate between steam-pressure-processed wheat and regular steam-rolled wheat. Differences in total energy gain, energy gain $/ \mathrm{kg}$ of feed, and the $\mathrm{NE}_{\mathrm{g}}$ figures also indicate that steam-pressure-processed wheat was utilized less efficiently than steam-rolled ( 8 minutes at atmo- 


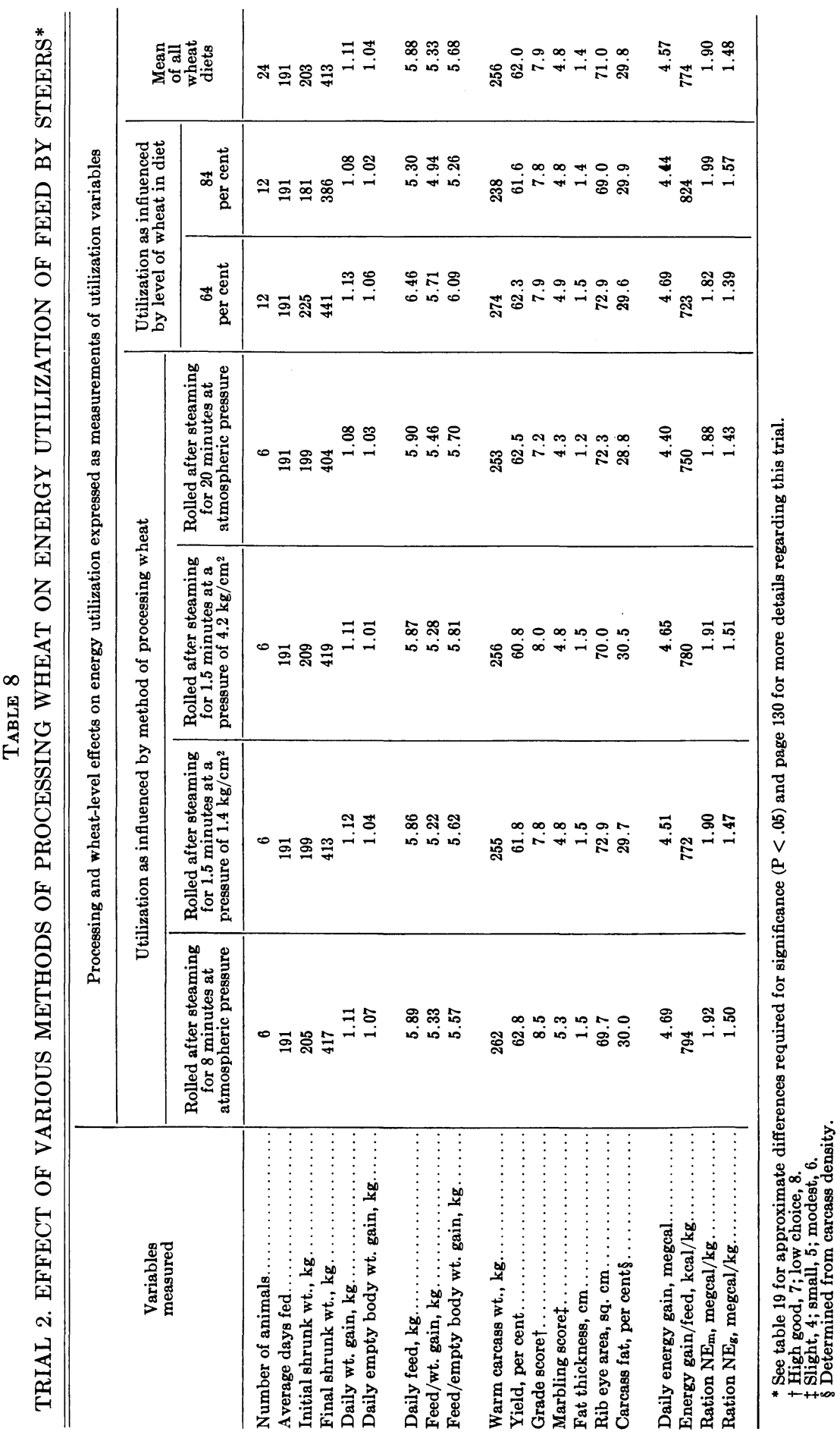




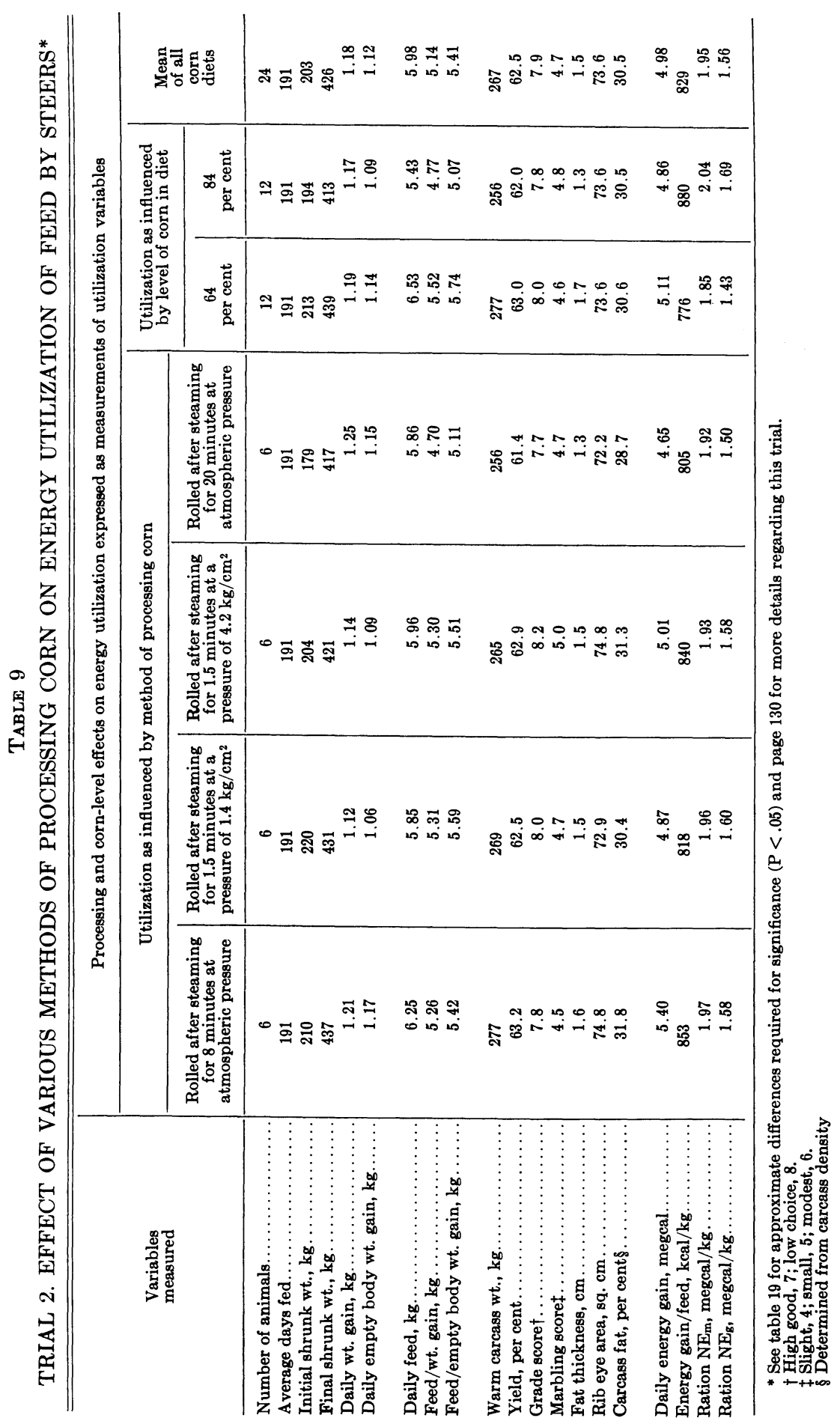




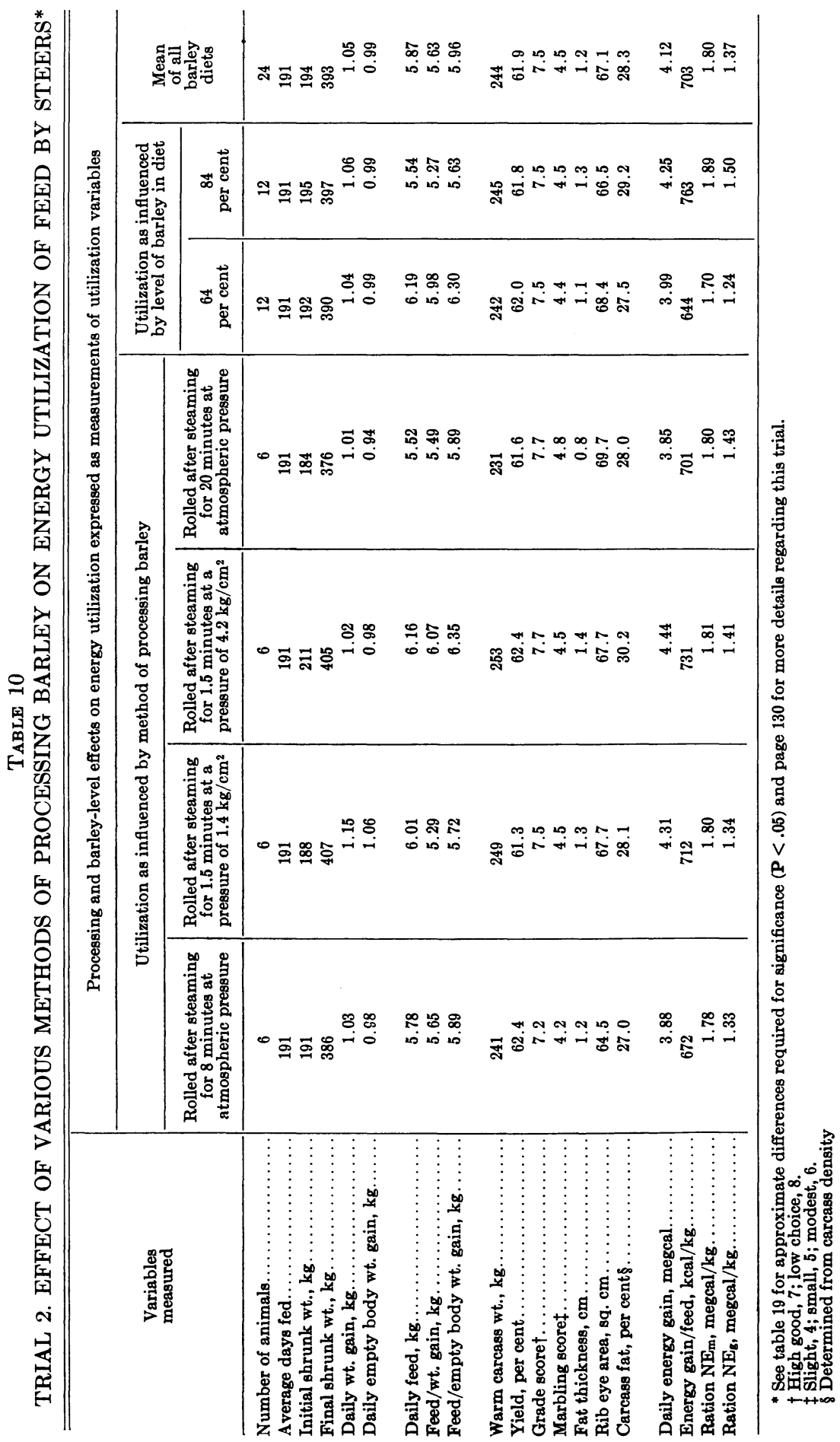




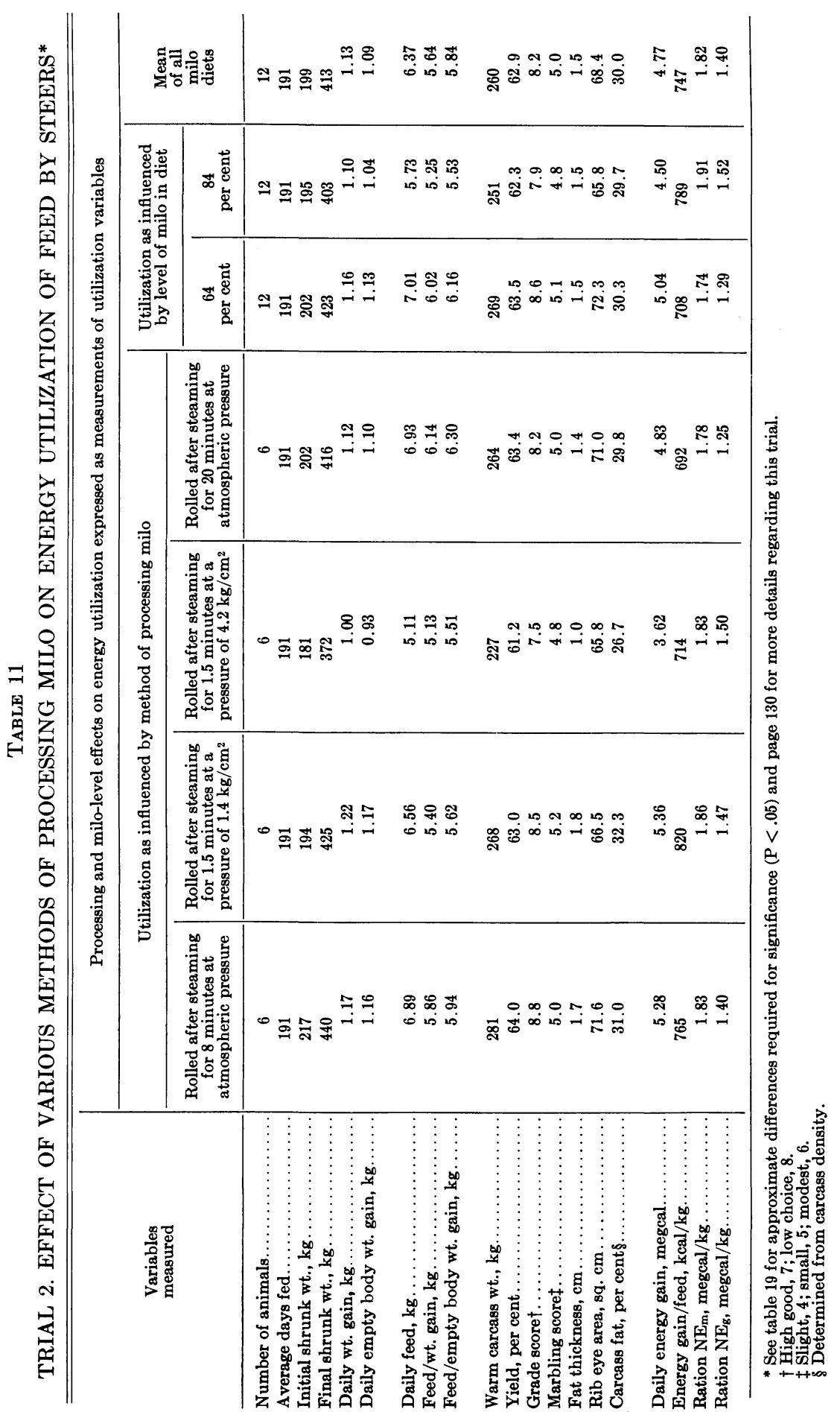


spheric pressure) or dry-heat-treated grain. Carcasses from cattle receiving the steam-rolled ( 8 minutes at atmospheric pressure) wheat were fatter $(\mathrm{P}<.05)$ than those receiving other treatments. Grade, marbling score, and fat thickness follow a similar trend except that differences between the 8 minutes at atmospheric pressure and dryheat treatment are small and not significant.

The response of steers fed milo in trial 5 (table 15) does not indicate the superiority of any one processing method. Trends are similar to those found in previous experiments, in that rations containing the steam-pressureprocessed milo were consumed in lower amounts than when the regular steamrolled milo was used. The dry-heattreated milo ration was also consumed in less quantity, but all measures of animal response are not significantly different between treatments.

The $\mathrm{NE}_{\mathrm{g}}$ figures obtained for the ration containing dry-heat-treated milo appear to be higher than those determined for the other rations. Part of this difference is probably due to a slightly higher grain content of this ration, as the dry heat treatment removed some moisture from the grain (table 4) and this was not completely compensated for at the time the rations were prepared. Actual dry-grain content of this ration was 73 per cent compared to an average of 71 per cent for the other rations.

\section{Results of paired-feeding trials 6,7 , and 8}

The results of the first paired-feeding experiment (trial 6 , table 16 ) indicate the pattern of response usually obtained when steam-pressure-processed milo ( 1.5 to $3.5 \mathrm{~kg} / \mathrm{cm}^{2}$ ) is compared to the regular steam-rolled milo (8 minutes at atmospheric pressure). Feed intake was lower, but feed efficiency and $\mathrm{NE}_{\mathrm{g}}$ values were improved by the steam-pressure processing. Differences in weight gain, energy gain, and in carcass characteristic are not significant.

Exact pair feeding was not achieved in trial 6 (see daily feed intake, table 16) mostly because of an inadequate correction for differences in moisture content between rations at the time of feeding. Nevertheless, there were no significant differences in animal response or net energy values when these two rations were fed in approximately equal amounts.

None of the differences shown in the comparison between the animals receiving the fresh ration and the ration prepared at intervals of 10 to 14 days are significant. The apparent increased feed intake of $0.5 \mathrm{~kg}$ /day for the fresh treatment appears large. When placed on the basis of body weight, however, the figures are 2.33 per cent for the fresh ration and 2.30 per cent for the ration prepared at longer intervals. The completely random assignment of animals to treatments did not in this instance result in equal initial weights. The similarity of response indieates that our usual procedure of preparing feed at intervals is not likely to have a detrimental effect on animal performance.

In the second pair-feeding experiment (trial 7, table 17) the steampressure-processed milo ration was consumed at too low a level to permit maximum gains. The consequence of this low-feed intake was a significant reduction in weight gain, energy gain, carcass weight, carcass fat content, and dressing percentage. Net energy values for the two rations are not different, which indicates that the feed consumed was utilized with about the same efficiency by both groups of steers. The pair-feeding portion of trial 7 , when the two rations were fed at the same level, indicates there were no differences in animal response, carcass char- 


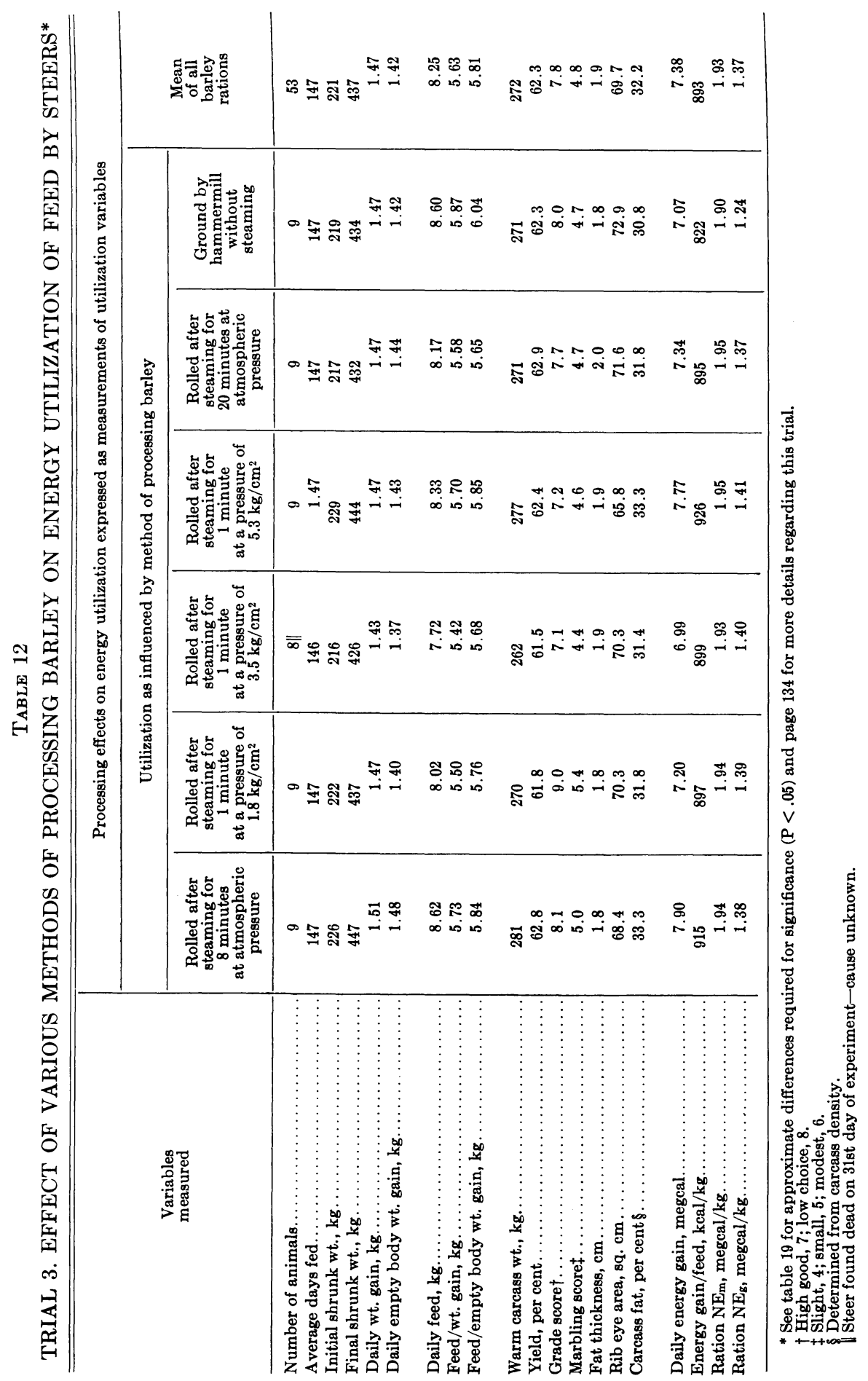




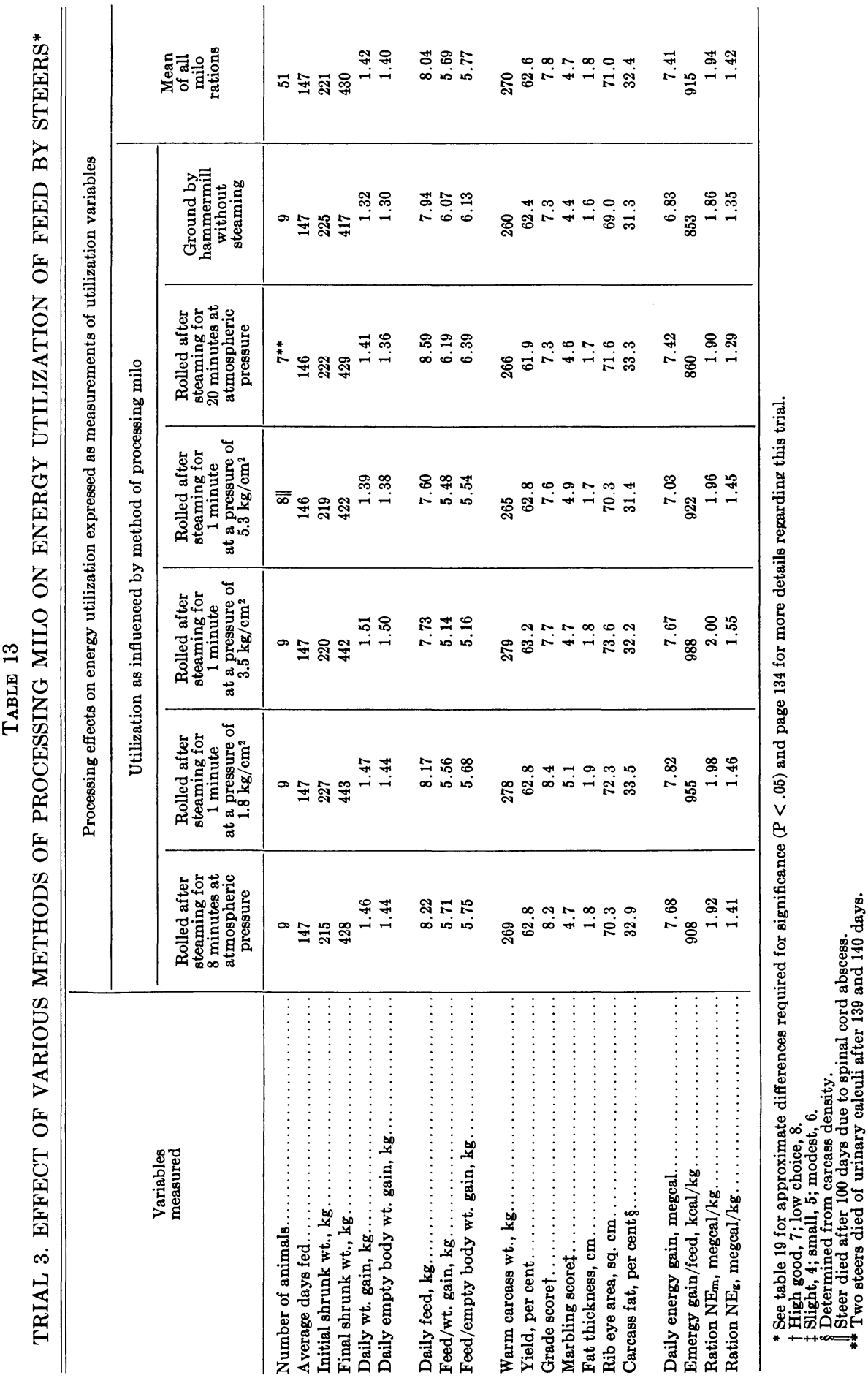




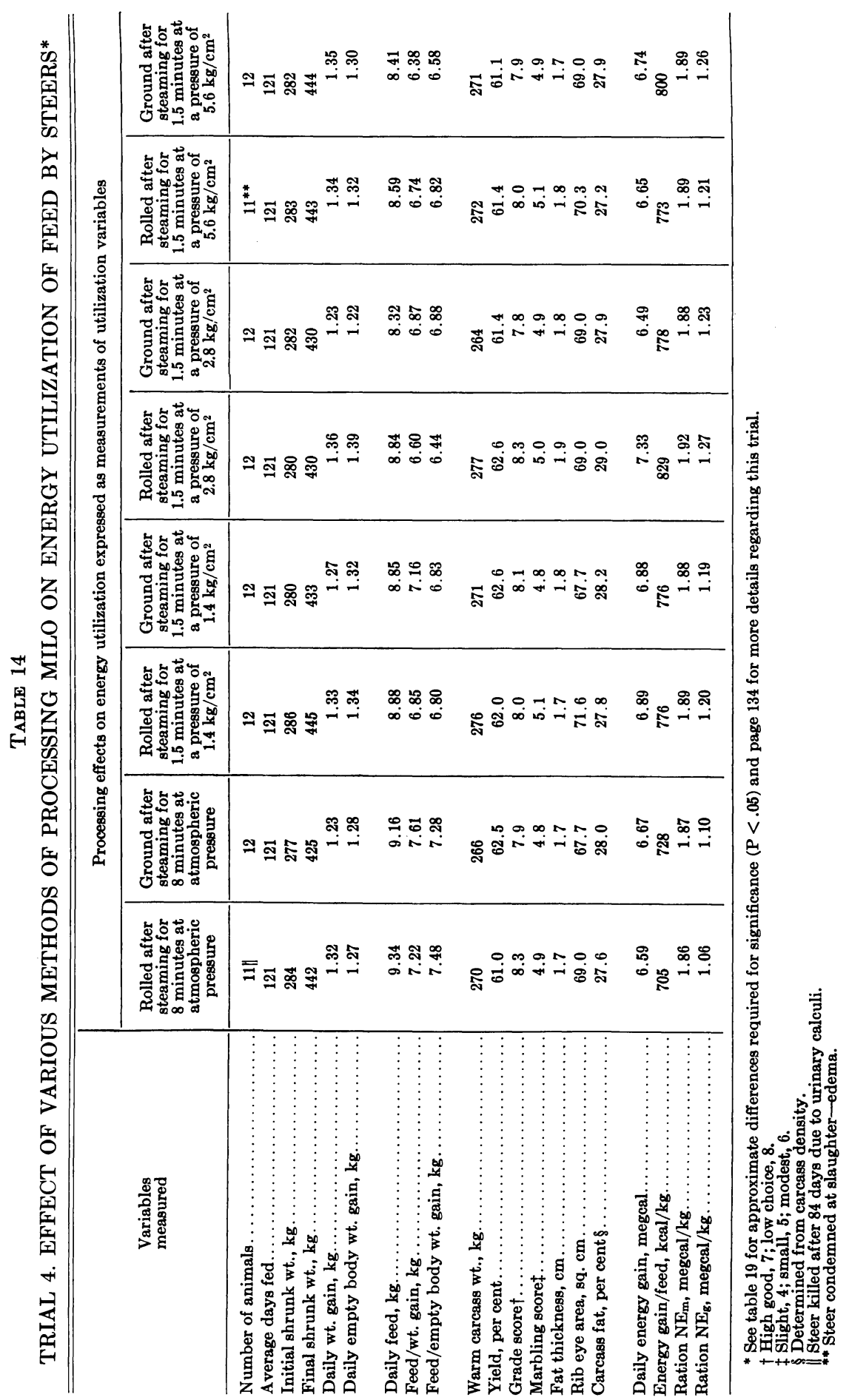




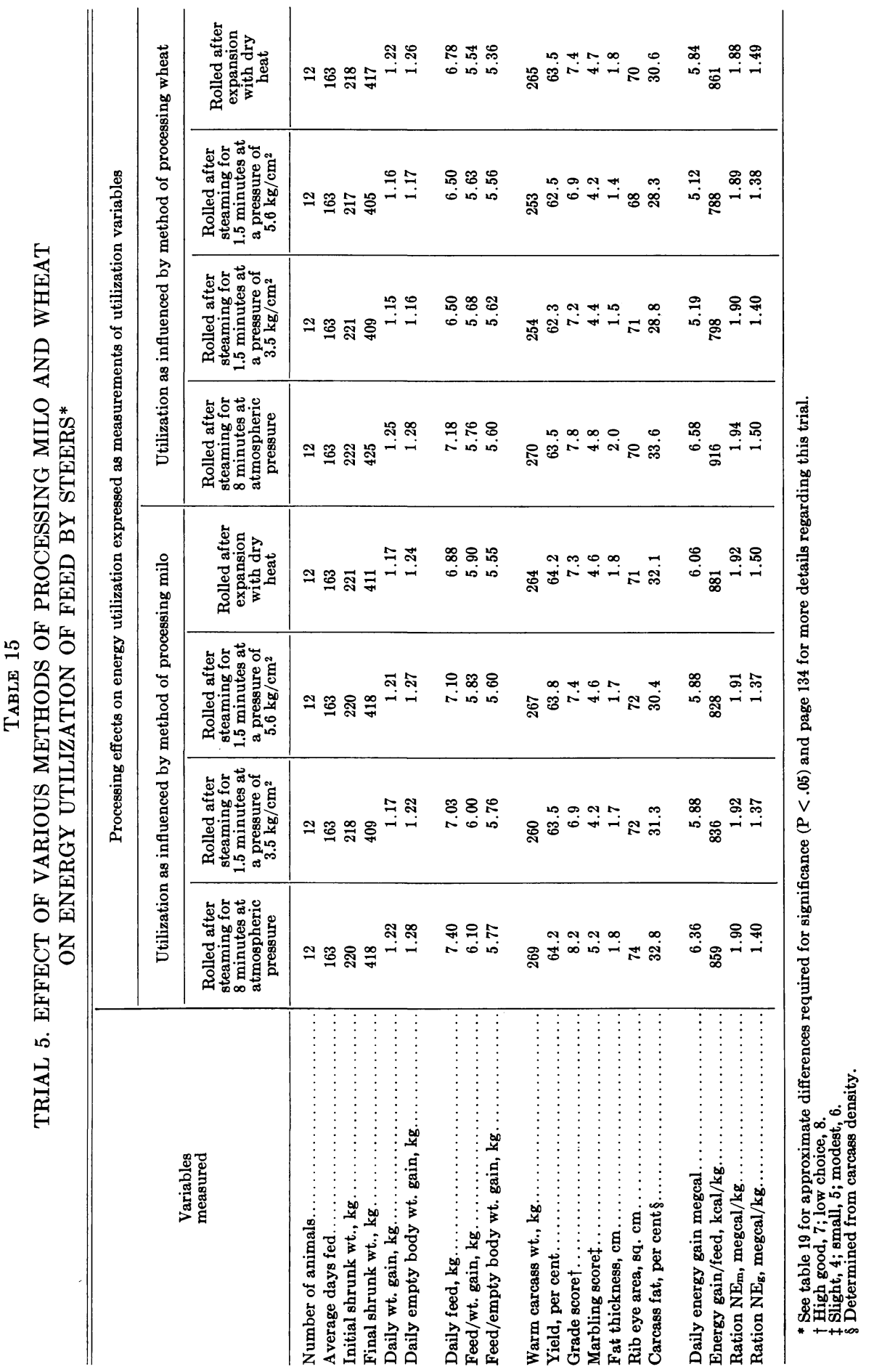


acteristics, or energy utilization attributable to the method of processing the milo.

Table 18 shows the results of trial 8 . This experiment was conducted primarily as a check on the method of determining net energy values (as explained under "Methods") and to determine the results of increasing moisture content of the ration containing regular steam-rolled milo. As in previous experiments, the ration containing steam-pressure-processed milo (1.5 minutes to $3.5 \mathrm{~kg} / \mathrm{cm}^{2}$ ) was consumed in lower amounts than was the ration containing steam-rolled grain (8 minutes at atmospheric pressure). Adding water to this last ration resulted in its being consumed in significantly reduced amounts, but apparent feed efficiency was also reduced to a level comparable to that found for the other ration $\left(1.5\right.$ minutes to $\left.3.5 \mathrm{~kg} / \mathrm{cm}^{2}\right)$. This difference was significant when data were analyzed on an empty-body basis.

Steers restricted to a low level of feeding (about $3.2 \mathrm{~kg} /$ day) made nearly comparable gains on each ration. However, the trend was for slightly higher empty body weight and energy gains by animals receiving steam-rolled milo.

Net energy values were calculated without the need for an assumption concerning fasting heat production, or by using an average value for the fasting-heat production. The two most significant findings are (1) that the ration containing the steam-pressure-processed milo had a higher $\mathrm{NE}_{\mathrm{g}}$ value than the ration containing the regular steam-rolled milo, and (2) that both procedures for determining $\mathrm{NE}_{\mathrm{g}}$ ranked rations in a similar manner. The assumed fasting-heat production method resulted in somewhat higher $\mathrm{NE}_{\mathrm{g}}$ (shown in parentheses, table 18); this is the result of a lower fasting-heat production determined for the steers of this experiment. The average fasting- heat production used in the other trials was $77 \mathrm{~W}_{\mathrm{kg}}^{0.75} \mathrm{kcal} /$ day, as compared to the $67 \mathrm{~W}_{\mathrm{kg}}^{0.75} \mathrm{kcal} /$ day found in this experiment.

An interesting result of trial 8 was the finding that additional moisture added to the regular steam-rolled milo ration (8 minutes-ap + water, table 18) apparently made this ration similar to the one containing steam-pressureprocessed milo ( 1.5 to $3.5 \mathrm{~kg} / \mathrm{cm}^{2}$ ). The possible significance of this finding is discussed on page 152.

\section{Digestion trials}

Table 20 shows results of the digestion trials. There were no significant differences in the digestible energy content of the rations fed in trial 2 which could be attributed to the method of processing the grain, but corn and wheat rations contained more digestible energy than did barley and milo rations. There was a significant $(\mathrm{P}<.05)$ grain $\times$ processing method interaction for nitrogen digestibility which is difficult to interpret. It is clear, however, that the steam-pressure processing of these grains was not detrimental to the digestibility of nitrogen. Digestibility of milo nitrogen was significantly $(\mathrm{P}<.05)$ below the other grains.

Results of the digestion trial associated with the third feeding experiment (table 20) indicate no significant influence attributable to the method of processing barley on either the digestible energy content or the digestibility of the nitrogen of the barley rations. The rations containing milo steampressure processed for 1 minute at either 3.5 or $5.3 \mathrm{~kg} / \mathrm{cm}^{2}$ contained more digestible energy than did the rations containing milo steamed for 8 or 20 minutes at atmospheric pressure or the ground grain. Nitrogen digestibility of milo was not influenced by the method of processing the grain but was significantly $(\mathrm{P}<.05)$ lower than that of the barley rations.

The digestion trial conducted in the 


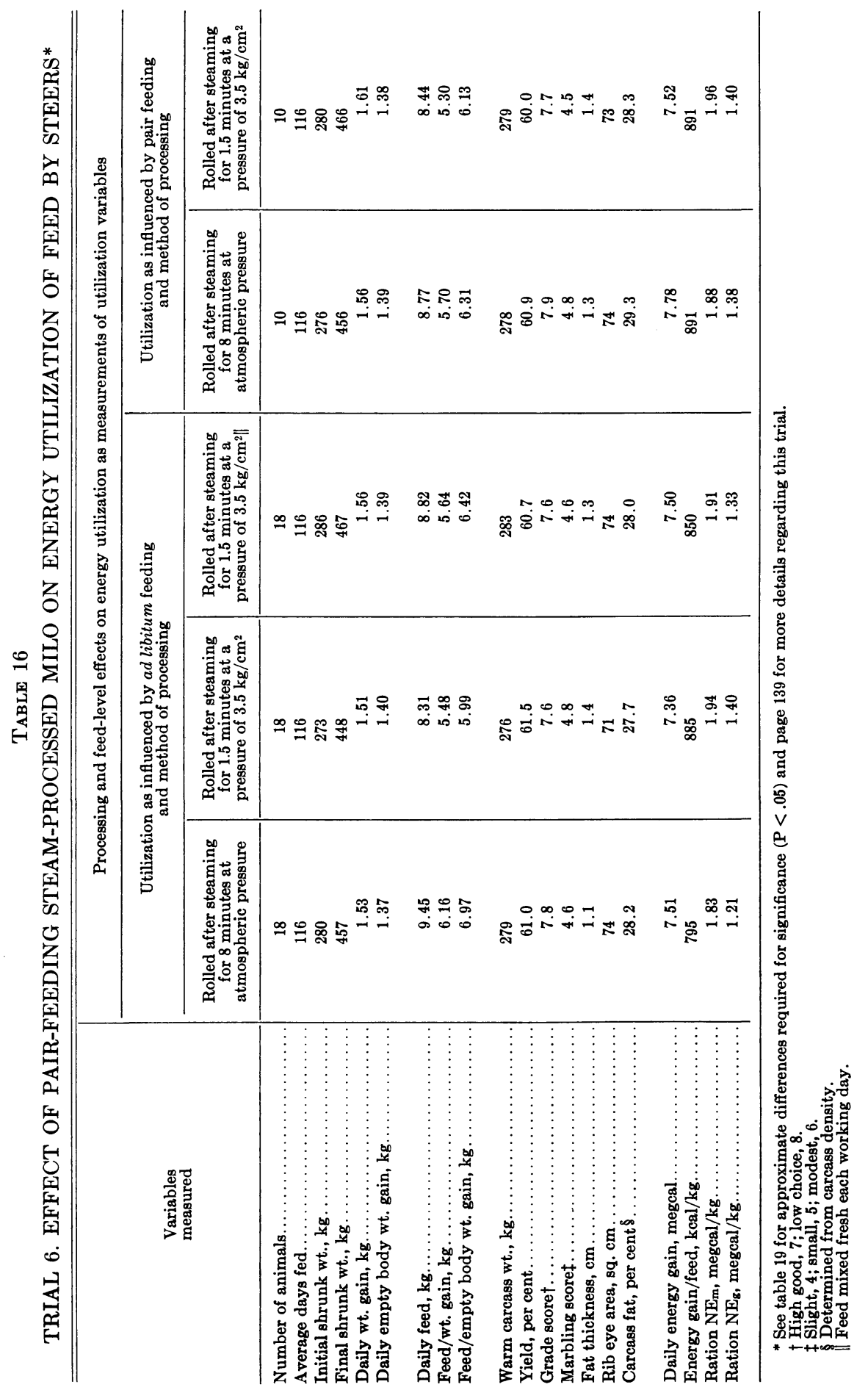




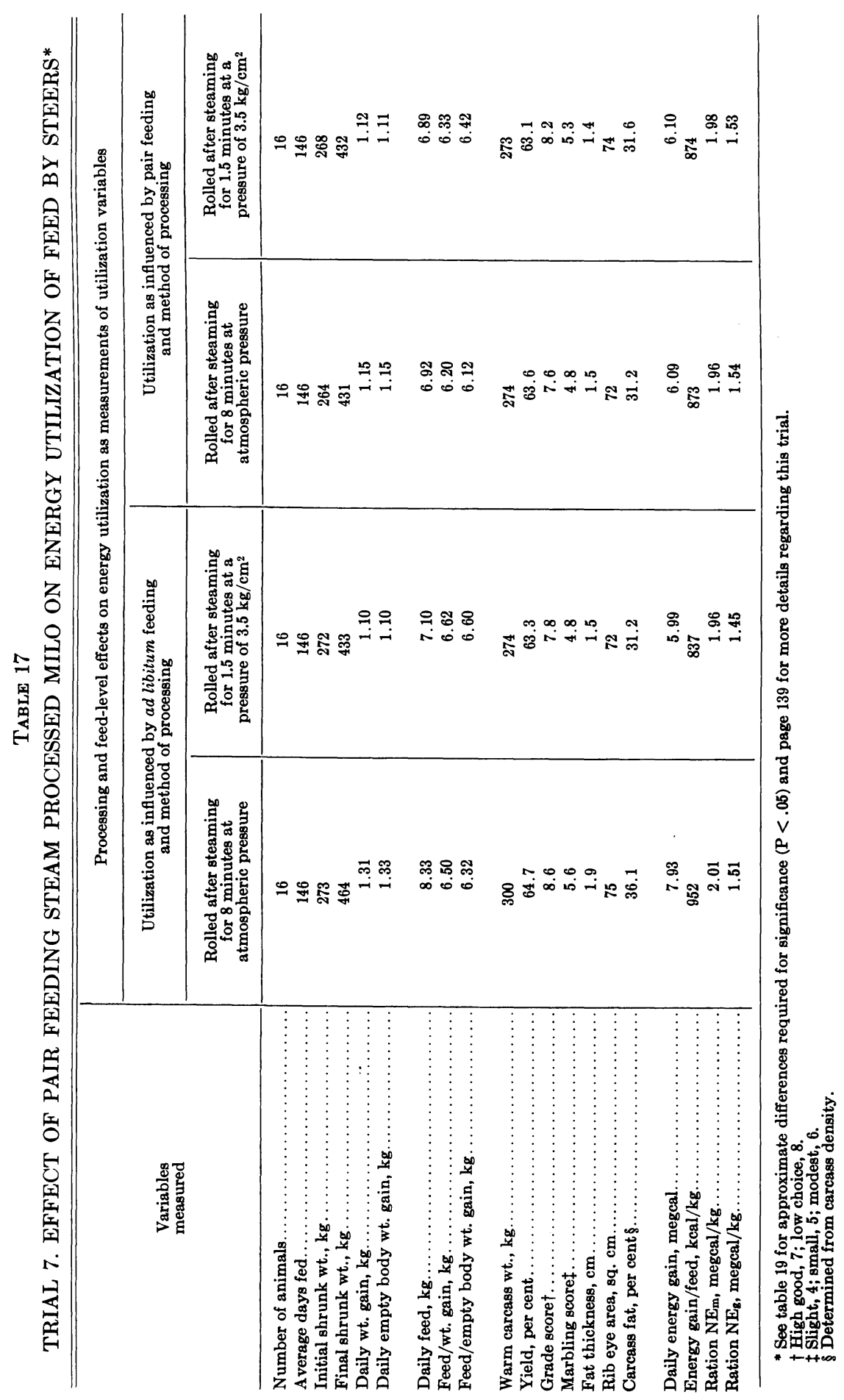




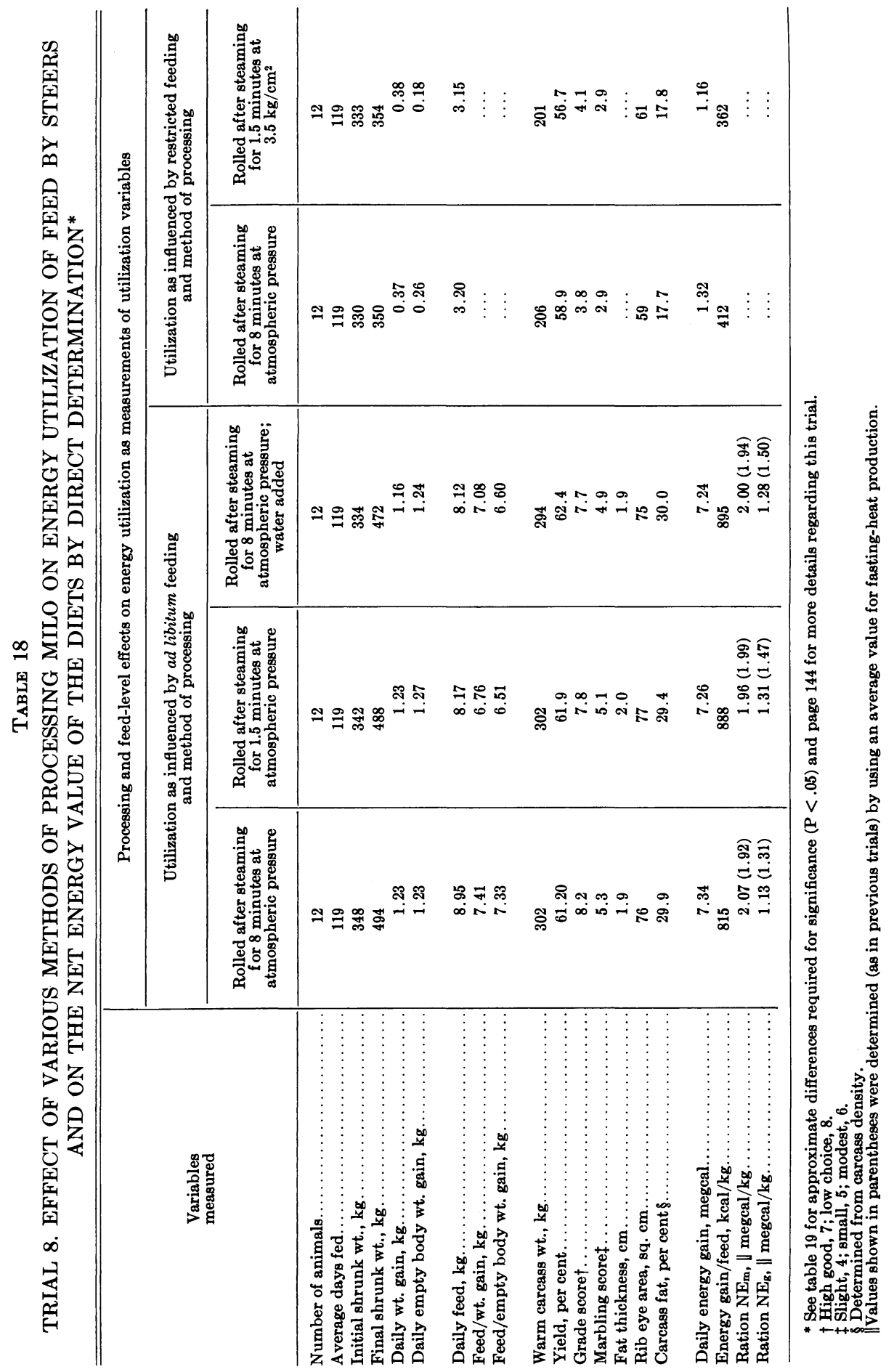




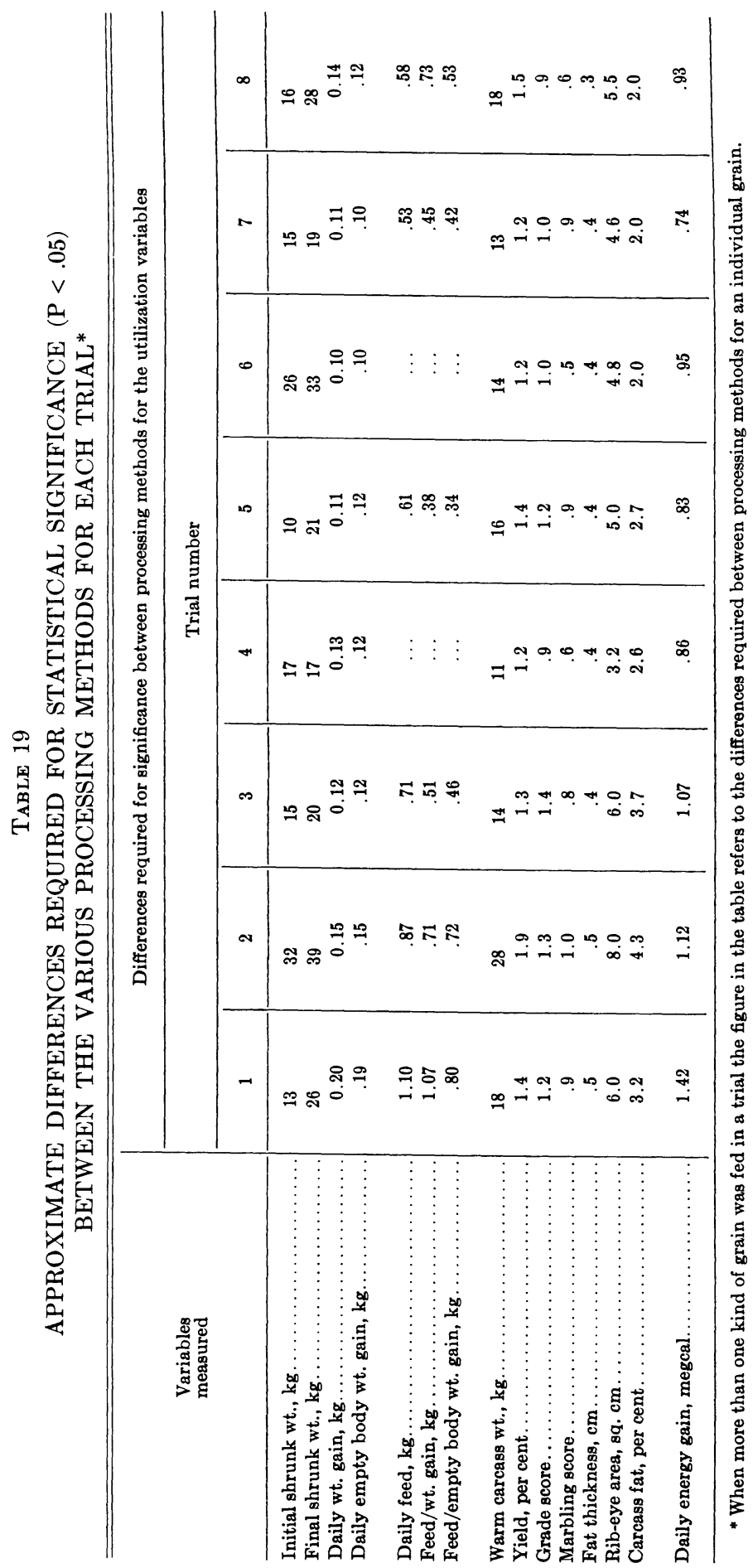


TABLE 20

EFFECT OF VARIOUS METHODS OF PROCESSING GRAIN ON THE DIGESTIBLE ENERGY CONCENTRATION AND THE DIGESTIBLE NITROGEN CONTENT OF THE DIETS FED IN TRIALS 2, 3, 4 AND 5

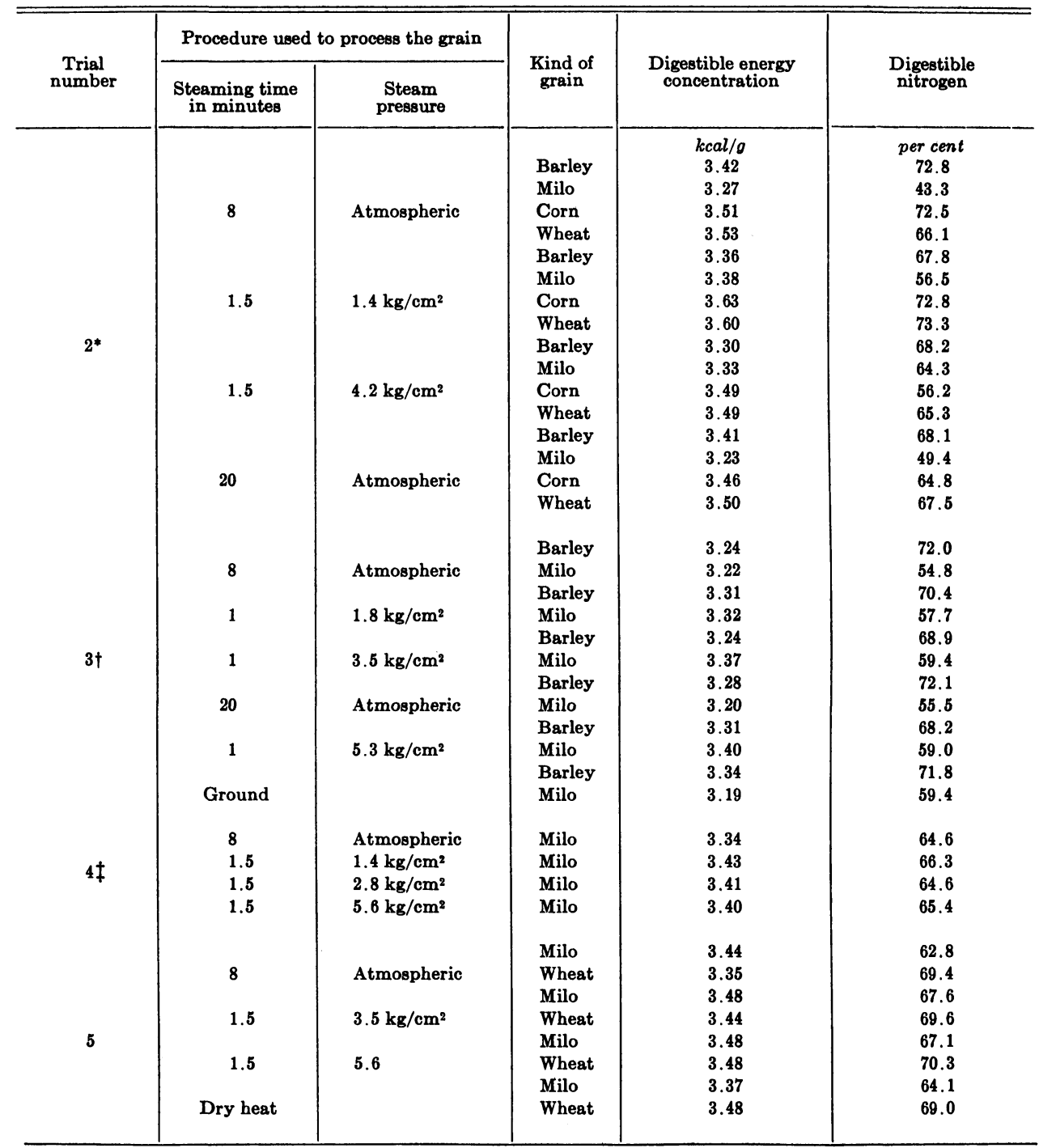

- Eighty-four per cent grain rations only. DE of barley and milo rations are significantly $(P<.05)$ lower than corn and wheat. There was a significant $(P<.05)$ grain $X$ processing method interaction for nitrogen digestibility. Overall, the digestibility of the nitrogen in the milo rations was significantly lower than in the rations containing the other grains.

t Rations containing milo processed by steaming under pressure at $3.5 \mathrm{~kg} / \mathrm{cm}^{2}$ and $5.3 \mathrm{~kg} / \mathrm{cm}^{2}$ are significantly higher in DE than are rations containing milo processed by steaming at atmospheric pressure.

$\ddagger$ Rolled grain rations only. 


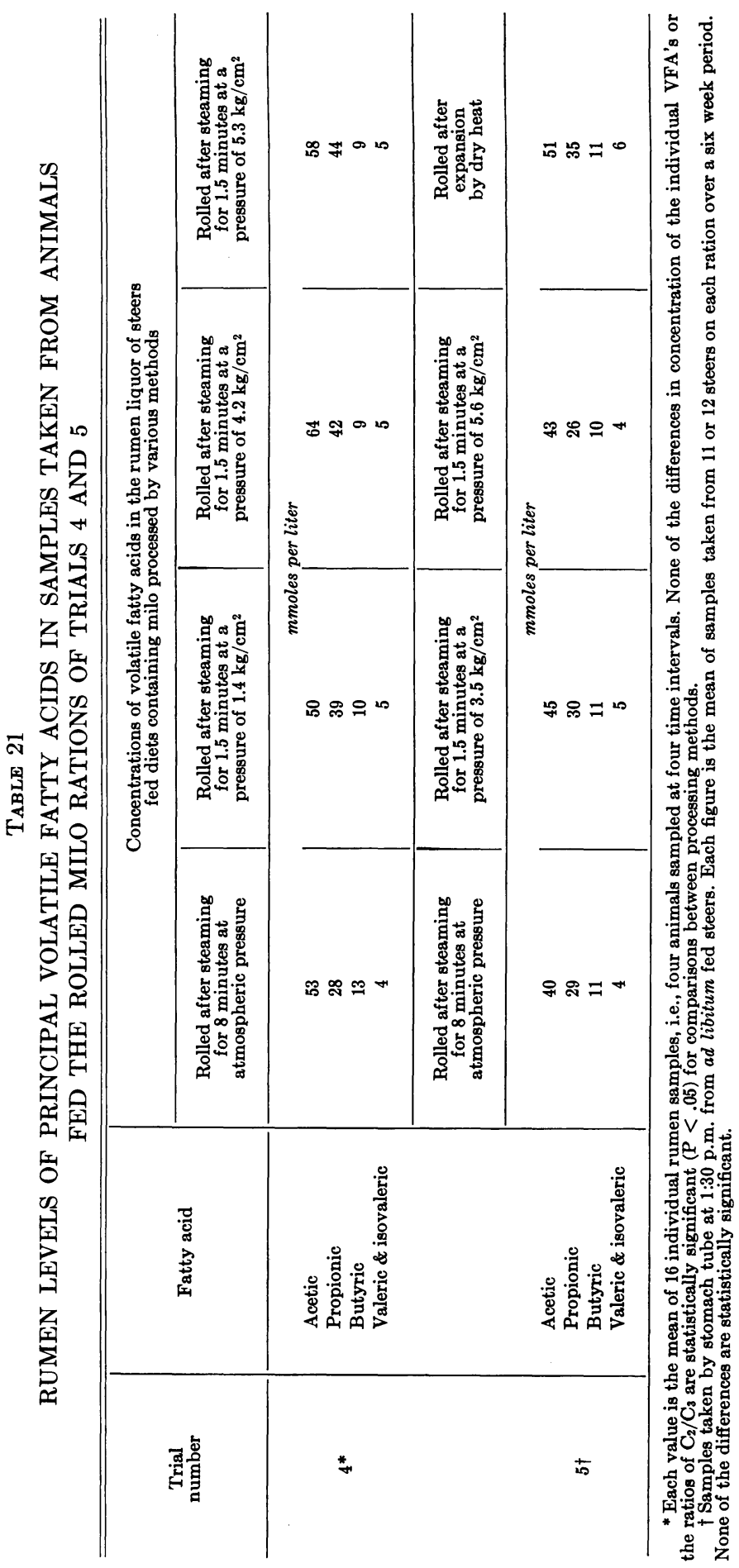


TABLE 22

DIGESTIBILITY OF AN 80 PER CENT STEAM PROCESSED MILO RATION IN DIFFERE.NT PARTS OF THE DIGESTIVE TRACT OF SHEEP AND CATTLE

\begin{tabular}{|c|c|c|c|c|}
\hline \multirow{3}{*}{ Variables measured } & \multicolumn{4}{|c|}{$\begin{array}{l}\text { Percentage digestibility of starch and dry matter } \\
\text { in the digestive tract of sheep and cattle }\end{array}$} \\
\hline & \multicolumn{2}{|c|}{$\begin{array}{l}\text { Digestibility when milo } \\
\text { was processed by steaming } \\
\text { for } 8 \text { minutes } \\
\text { at atmospheric pressure }\end{array}$} & \multicolumn{2}{|c|}{$\begin{array}{c}\text { Digestibility when milo } \\
\text { was processed by steaming for } \\
1.5 \text { minutes at a pressure of } \\
3.5 \mathrm{~kg} / \mathrm{cm}^{2}\end{array}$} \\
\hline & Fed to cattle & Fed to sheep & Fed to cattle & Fed to sheep \\
\hline & \multicolumn{4}{|c|}{ per cent } \\
\hline Digestibility in forestomachs ${ }^{*} \dagger \neq \ldots \ldots \ldots \ldots$ & 71.3 & 63.1 & 68.7 & 66.3 \\
\hline Starch digestion in forestomachs $\downarrow \ddagger \ldots \ldots \ldots$ & 89.3 & 90.3 & 94.5 & 95.9 \\
\hline Over-all dry matter digestibility $\ddagger \ldots \ldots \ldots \ldots$ & 83.4 & 80.2 & 83.5 & 83.4 \\
\hline Over-all starch digestibility $\ddagger \ldots \ldots \ldots \ldots \ldots$ & 96.9 & 97.6 & 96.4 & 98.7 \\
\hline Concentration of starch in the abomasum*. & 28.2 & 16.5 & 14.8 & 7.7 \\
\hline
\end{tabular}

* Organic matter basis for sheep and dry matter basis for cattle.

$\dagger$ Rumen, reticulum and omasum.

$\ddagger$ Estimated by the lignin ratio technique.

rolled milo rations of feeding experiment 4 did not show a statistically significant difference in the digestibility of energy or nitrogen. The trend was to a higher digestible energy content of the steam-pressure-processed milo ration (as in previous experiments). Results of the digestion trial conducted in conjunction with trial 5 are also shown in table 20. Again, the trend is to slightly increased digestible energy and digestible protein when milo is processed at 3.5 or $5.6 \mathrm{~kg} / \mathrm{cm}^{2}$ steam pressure, but the means are not significantly different.

\section{Volatile fatty acid levels and starch digestion}

Table 21 gives the results of experiments designed to measure volatile fatty acid (VFA) levels in the rumina of steers receiving the rolled milo rations fed in feeding trials 4 and 5. Differences due to sampling times were significant $(\mathrm{P}<.05)$ in trial 4. Processing method, however, was without a statistically significant influence on VFA concentrations or the $\mathrm{C}_{2} / \mathrm{C}_{3}$ ratio in either trial.
Table 22 summarizes findings of the experiments conducted to determine the influence of grain processing on starch digestion in various segments of the intestinal tract of sheep and cattle; these findings have been published by Holmes, Drennan and Garrett (1970). Over-all starch disappearance from the gastrointestinal tract averaged 97.3 and 97.6 per cent for the grain steamed at atmospheric pressure and the steampressure-processed grain, respectively. Starch fermented in the rumen average 90 and 95 per cent for steamed and pressure-steamed grain. These results seem to eliminate the possibility that more starch escapes rumen fermentation when grain has been steamed under pressure, and suggest that over-all starch digestion has not been improved by the pressure-steaming treatment.

The data from this trial indicated a more rapid fermentation when steampressure-processed grain was fed. This more rapid fermentation could result in increased blood levels of the volatile fatty acids, which in turn might have a depressing effect on the food intake of the animals. 


\section{DISCUSSION}

The general finding in these experiments has been a lack of statistically significant differences for the various parameters of feedlot response when cattle were fed wheat, corn, or barley processed by various steam or heat treatments. This indicates that there are alternate procedures for processing these grains which can be expected to produce results essentially equivalent to a regular steam-rolling procedure ( 8 to 10 minutes steaming at atmospheric pressure before rolling).

The results of the experiments with milo have been more variable but some patterns are apparent. The general finding is a lower feed consumption but an improved feed efficiency (feed/gain ratio and $\mathrm{NE}_{\mathrm{g}}$ value) when milo is processed under steam pressure. An optimum time-pressure combination cannot be determined with precision, but it appears that severe steam treatment ( 1.5 minutes at $4.2 \mathrm{~kg} / \mathrm{cm}^{2}$ and above) can sometimes result in slower gains (due to the lower feed intake) and a less desirable feed/gain ratio than somewhat lower steam pressure treatments (1.5 minutes at 2.8 to 3.5 $\left.\mathrm{kg} / \mathrm{cm}^{2}\right)$. This is not an invariable finding, as is evidenced by the excellent performance of steers in trial 4 consuming rations which contained milo processed for 1.5 minutes at $5.6 \mathrm{~kg} / \mathrm{cm}^{2}$. Also, in trial 5 there were no differences in animal response or energy utilization between rations containing milo processed at 5.6 and $3.5 \mathrm{~kg} / \mathrm{cm}^{2}$ steam pressure.

The most consistent finding - a decreased intake of rations containing steam-pressure-processed milo - raised questions concerning the role of food consumption. The pair-feeding experiments (trials 6 and 7, tables 16 and 17) generally indicate a similar response when the steam-rolled and steam-pressure-processed milo rations were fed at nearly identical levels. The results of trial 8 (table 18) show that water added to the regular steam-rolled milo ration resulted in a depressed intake with an apparent improvement in energy utilization. This lends support to the results of the pair-feeding trials, since the intake was then comparable to that found with the ration containing the steampressure-processed milo.

The literature concerning effect of level of food consumption on energy utilization (A.R.C., 1965) indicates a greater fecal loss of energy as the intake of dry matter increases. This is partly compensated for by a relatively lower production of methane, and lower urinary energy losses, but over-all the metabolizable energy concentration (kcal/g) is usually higher for the same ration fed at lower levels.

In only one digestion trial out of four was it possible to demonstrate a statistically significant improvement in the digestibility of the energy of the rations containing the steam-pressureprocessed milo. The trend in all trials, however, was in the direction of a slight improvement in DE content. This increase in digestibility could amount to approximately $80 \mathrm{kcal}$ of metabolizable energy per $\mathrm{kg}$ of ration. If we assume the efficiency of utilization of ME for energy gain is in the order of 50 per cent, this increase of $80 \mathrm{kcal} / \mathrm{kg}$ could account for approximately 20 per cent of the increase noted in the $\mathrm{NE}_{\mathrm{g}}$ figures determined for steam-pressure-processed grain rations.

A further possibility explored was that more starch escaped rumen fermentation with absorption further down the gastrointestinal tract when the grain was processed under steam pressure. This would eliminate a loss of energy due to microorganism action, and would make additional efficiencies possible as a result of the metabolic 
pathways involved in the utilization of glucose rather than volatile fatty acids. The findings shown in table 22, which indicate that more rather than less starch is fermented in the rumen when animals are fed the steam-pressureprocessed grain, effectively eliminate this as a tenable explanation.

The possibility of a shift in rumen fermentation resulting in a greater proportion of propionic acid being produced could also be advanced as another partial explanation for improved feeding value of steam-pressure-processed milo. Results in table 21 indicate a non-significant and somewhat inconsistent shift in the direction of more propionate, but in view of results in the literature (Elliot et al., 1965; Orskov and Allen, 1966 and Orskov et al.,1966) even a real shift of the magnitude noted could hardly account for differences found in the utilization of the energy of the steam-pressure-processed milo compared to the regular steam-rolled product.

The more rapid fermentation associated with the ingestion of the steampressure-processed milo could be one of the major factors responsible for the depressed intake of the rations containing the steam-pressure-processed grain. It has been shown that propionate infusion will have a depressing influence on the appetite of steers fed high-grain diets (Theurer et al., 1969), and increased levels of blood propionate might occur if rapid fermentation was present.

It appears that improved utilization of the steam-pressure-processed milo by fattening steers is the end result of a combination of small individual influences working in the same direction. The basic factors seem to be a small increase in digestibility and a change in the rate and perhaps the pattern of fermentation. The consistent finding of a lower feed intake associated with the rations containing steam-pressure-processed milo, together with information from paired-feeding experiments and results obtained when water was added to regular steam-rolled milo, provides substantial evidence to suggest that reductions in feed intake (whether brought about by the processing method, by physical restriction, or by the addition of water) were associated with an improved energy utilization.

From a practical viewpoint the most significant findings of this investigation are that (1) feeding value of barley, wheat, and corn is relatively unchanged by processing under steam pressure, and (2) that energy utilization of milo is increased by treatment with steam under pressure. However, a severe steam-pressure treatment sometimes results in feed intakes so reduced that animal gains are adversely influenced.

\section{SUMMARY}

Comparative slaughter-feeding experiments with beef steers were conducted to determine the influence of various steam-processing treatments on energy utilization and feeding value of wheat, corn, barley, and milo. The general finding was a lack of statistically significant differences in the various parameters of feedlot response for eattle fed wheat, corn or barley; that is, processing these three grains by various steam-pressure-time combinations did not consistently improve their value when compared to processing by a regular steam-rolling procedure (8 minutes steaming at atmospheric pressure).

In the experiments reported, steampressure processing of milo has resulted in an 8 per cent improvement in feed efficiency (feed/gain) of feedlot steers and improved the $\mathrm{NE}_{\mathrm{g}}$ of the high-grain rations by an average of 10 per cent. Optimum time-pressure steam treat- 
ment may be variable, but apparently was approximately $1.5 \pm 0.5$ minutes at $3.5 \pm 0.5 \mathrm{~kg} / \mathrm{cm}^{2}$.

In all experiments in which ad libitum consumption was permitted, animals fed steam-pressure-processed milo consumed less feed than animals receiving regular steam-rolled grain. However, if feed intake of the pressureprocessed grain was 88 per cent or more of the intake obtained when the same grain was steamed for 8 to 10 minutes at atmospheric pressure before rolling, an improvement in feed efficiency as measured by feed/grain ratio was apparent. In these experiments, differences in daily gains or in carcass characteristics were not found. When consumption of steam-pressure-processed milo was less than 88 per cent of the steam-rolled milo, lower weight gains (with associated detrimental influence on the carcass) occurred. Even with lower gain, gross feed efficiencies and net energy values were as good or better for steam-pressure-treated milo.

Digestion trials have indicated about a 3 per cent increase in digestible energy content of rations containing steam-pressure-processed milo. This was statistically significant $(\mathrm{P}<.05)$ in one out of four experiments, but is not of sufficient magnitude to explain all of the observed increase in the net energy value of steam-pressure-processed milo. The steam-pressure treat- ments were not detrimental to the digestibility of nitrogen.

The slight improvement in digestibility of milo as a result of the steampressure treatment is apparently related to food intake, since in the pairedfeeding experiment it was not possible to demonstrate a difference in the efficiency of energy utilization between rations containing pressure-steamed grain and those containing milo steamed at atmospheric pressure. Slightly more starch was fermented by the rumen microorganisms in animals fed the steam-pressure-processed milo as compared to that found in those fed the regular steam-rolled grain. However, over-all starch digestion in the entire digestive tract was not different.

Higher net energy values usually associated with rations containing steampressure-processed milo are partly the result of a slight improvement in digestibility. This increase in digestibility may be related to a lower feed intake of these rations which is most likely the result of a more rapid rate of fermentation of the steam-pressureprocessed milo. The more rapid rate of fermentation may also be more efficient and thus may help account for the improved net energy values, although analysis of rumen samples for presence of volatile fatty acids did not reveal statistically significant differences which would support this conclusion.

\section{ACKNOWLEDGMENTS}

The first three experiments in this study were conducted under contract USDA 12-14-100-7753 (44) between the United States Department of Agriculture and the University of California. The FMC Corporation donated the use of equipment used to steam-pressure-process the grain. Dr. H. G. Walker, Dr. G. O. Kohler, and Mr. W. C. Rockwell, of the Agricultural Research Service, U.S.D.A., Albany, California, were cooperators on trial 5 and were responsible for processing the milo and wheat by the dry-heat treatment. Agway Incorporated, Syracuse, New York provided financial assistance for trial 5.

Y. J. Nakata, W. H. Shouse, O. E. Del Valle, and M. Velasco assisted in the conduct of the digestion trials and in analysis of rumen samples for volatile fatty acids. J. H. G. Holmes and 
M. J. Drennan conducted the studies concerned with starch digestion in the various parts of the ruminant digestive Hinman assisted in writing the computer programs used to analyze the data.

\section{LITERATURE CITED}

A. R. C.

1965. The nutrient requirements of farm livestock, No. 2. Ruminants. Agric. Res. Council, London.

Armstrong, D. G. and K. L. Blaxter

1957. The heat increments of steam volatile fatty acids in fasting sheep. British J. Nutr. 11:392.

Balch, C. C., D. A. Balch, S. Bartlett, G. O. Hasking,

V. W. Johnson, S. W. Rowland, and J. TURNER

1955. Studies of the secretion of milk in low fat content by cows on diets low in hay and high in concentrate. V. The importance of the type of starch in the concentrate. J. Dairy Res. 22:10.

BLAXTER, K. L.

1962. The Energy Metabolism of Ruminants. London: Hutchinson.

Blaxter, K. L., and F. W. Wainman

1964. The utilization of different rations by sheep and cattle for maintenance and fattening. J. Agric. Sci. 63:113.

Elliot, J. M., D. E. Hogue, G. S. Meyers, JR., and J. K. Loosli

1965. Effect of acetate and propionate on the utilization of energy by growing-fattening lambs. J. Nutrition 87:233.

Ensor, W. L., J. C. Shaw, and H. F. Tellechea

1959. Special diets for the production of low-fat milk and more efficient gain in body weight. J. Dairy Sci. 42:189.

ERwin, E. S., G. J. Marco, and E. M. Emory

1961. Volatile fatty acid analysis of blood and rumen fluid by gas chromatography. J. Dairy Sci. 44:1768.

GARRETt, W. N., J. H. Meyer, and G. P. Lofgreen

1959. The comparative energy requirements of sheep and cattle for maintenance and gain. J. Anim. Sci. 18:528.

GarRetT, W. N., and N. Hin MaN

1968. Re-evaluation of the relationship between carcass density and body composition of beef steers. J. Anim. Sci. 28:1.

Hale, W. H., L. Cuitun, W. J. Saba, B. Taylor, and B. Theurer

1966. Effect of steam processing and flaking milo and barley on performance and digestion by steers. J. Anim. Sci. 25:392.

Holmes, J. H. G., M. J. Drennan, and W. N. GarretT

1970. Digestion of steam processed milo by ruminants. J. Anim. Sci. 31:409.

Keating, E. K., W. J. Saba, W. H. Hale, and B. Taylor

1965. Further observations on the digestion of milo and barley by steers and lambs. J. Anim. Sci. 24:1080.

LOFGREEN, G. P.

1965. A comparative slaughter technique for determining net energy values with beef cattle. Third Symposium on Energy Metabolism, K. L. Blaxter (ed.). London: Academic Press Inc.

Lofgreen, G. P., and W. N. Garrett

1968. A system for expressing net energy requirements and feed values for growing and finishing beef cattle. J. Anim. Sci. 27:793.

Orskov, E. R., and D. M. Allen

1966. Utilization of salts of volatile fatty acids by growing sheep. 1. Acetate, propionate and butyrate as sources of energy for young, growing lambs. British J. Nutr., 20:307. 
Orskov, E. R., F. D. HovelL, and D. M. AlleN

1966. Utilization of salts of volatile fatty acids by growing sheep. 2. Effect of stage of maturity and hormone implantation on the utilization of volatile fatty acid salts as sources of energy for growth and fattening. British J. Nutr. 20:307.

Shaw, J. C., R. R. Robinson, M. E. Senger, S. Lakshmanan, and T. R. Lewis

1959. Production of low-fat milk. I. Effect of quality and quantity of concentrate on the volatile fatty acids of the rumen and the composition of milk. J. Nutrition 69:235.

Theurer, B., J. Trei, and W. H. Hale

1967. In vitro VFA production as influenced by steam processing and flaking of milo and barley. Proc. West. Sec. Am. Soc. Anim. Sci. 18:201.

Theurer, B., W. H. HALE, and T. SAWYer

1969. Effect of intrajugular infusions of sodium propionate, butyrate or valerate on feed intake. J. Anim. Sci. 29:173 (abstract).

To simplify the information, it is sometimes necessary to use trade names of products or equipment. No endorsement of named products is intended nor is criticism implied of similar products not mentioned. 

The journal HILGARDIA is published at irregular intervals, in volumes of about 650 to 700 pages. The number of issues per volume varies.

Single copies of any issue may be obtained free, as long as the supply lasts; please request by volume and issue number from:

$$
\begin{aligned}
& \text { Agricultural Publications } \\
& \text { University of California } \\
& \text { Berkeley, California } \mathbf{9 4 7 2 0}
\end{aligned}
$$

The limit to nonresidents of California is 10 separate titles. The limit to California residents is 20 separate titles.

The journal will be sent regularly to libraries, schools, or institutions in one of the following ways:

1. In exchange for similar published material on research.

2. As a gift to qualified repository libraries only.

3. On a subscription basis $-\$ 7.50$ a year paid in advance. All subscriptions will be started with the first number issued during a calendar year. Subscribers starting during any given year will be sent back numbers to the first of that year and will be billed for the ensuing year the following January. Make checks or money orders payable to The Regents of The University of California; send payment with order to Agricultural Publications at above address. 